\title{
TECTONIC EVOLUTION OF THE SERGIPANO BELT, NE BRAZIL
}

\author{
LUIZ JOSÉ HOMEM D'EL-REY SILVA
}

\begin{abstract}
The Sergipano Belt is a ESE-WNW trending, sub-greenschist to amphibolite grade metavolcano-sedimentary wedge between the southern part of the Borborema Province, known as the PernambucoAlagoas Massif, and the São Francisco Craton, in NE Brazil, polydeformed and metamorphosed about $650 \mathrm{Ma}$ ago. From $\mathrm{S}$ to $\mathrm{N}$ the belt comprises a domain of cratonic sediments, and two metavolcano-sedimentary domains, deposited around mantled Archean-Paleoproterozoic basement gneiss domes. The northern part of the belt also encloses a domain of migmatites and two igneous domains, and is intruded by several syn- to late-tectonic granitic bodies. Intensive geological mapping (1:50,000 and 1:100,000 scales) carried out in a key area of the southern part of the belt, has provided abundant stratigraphic and structural data allowing to interpret the tectonic evolution of the belt in terms of the closure of an asymmetric, laterally continuous basin infilled under a syn-depositional extensional regime and evolving into an oceanic basin (the Canindé sea). The structural analysis indicates a basement-involved $\mathrm{D}_{1}-\mathrm{D}_{3}$ ductile to brittle-ductile deformational evolution, $\mathrm{D}_{2}-\mathrm{D}_{3}$ being associated with a sinistral transpression throughout the belt. The closure of the Canindé* sea was probably followed by an oblique collision of the Borborema Province with the São Francisco Craton, then leading to the inversion of the extensional faults of the opening of the basin, and providing the ingredients to understand the lithotectonic domains and the evolution of the Pernambuco-Alagoas Massif. Most tectonic features of the Sergipano Belt fit with those found in other mobile belts of the Pan-African/Brasiliano orogeny, and suggest a model compatible with the supercontinent that evolved by fragmentation and amalgamation along long-lived zones of lithosphere weakness throughout the Proterozoic.
\end{abstract}

RESUMO A Faixa Sergipana é uma cunha metavulcanossedimentar de direção WNW-ESE, situada na parte sul da Provfncia Borborema, entre o Maciço Pernambuco-Alagoas e o Craton de São Francisco, no NE do Brasil, que foi polideformada e metamorfisada até o fácies anfibolito, localmente atingindo anatexia, há aproximadamente $650 \mathrm{Ma}$. De sul para norte, a faixa compreende um dominio de sedimentos cratonicos e dois dominios metavulcanossedimentares, depositados em torno de domos gndissicos do embasamento arqueanopaleoproterozóico. Na parte norte, onde tambem existem um domfnio de migmatitos e dois dominios igneos, ocorrem diversos corpos graniticos sin a tardi tectônicos. Mapeamento geológico intensive (escalas 1:50.000 e 1:100.000) realizado em drea chave na parte sul da Faixa Sergipana possbilitou a coleta de abundantes dados estratigraficos e estruturais que permitem interpretar a sua evolução tectônica em termos do fechamento de uma bacia asimetrica e lateralmente contínua, que foi preenchida durante a tectônica extensional e provavelmente evoluiu para abertura de um oceano (Mar do Canindé. Embasamento e cobertura foram envolvidos em deformação polifasica $\mathrm{D}_{1}-\mathrm{D}_{3}$ dúctil a dúctil-ruptil, evidenciando evolução monociclica progressiva, sendo $\mathrm{D}_{2}-\mathrm{D}_{3}$ associadas com transpressao sinistral. O fechamento do mar do Canindé completou-se provavelmente através de uma colisão oblíqua do Craton São Francisco com a parte sul da Província Borborema, ocasionando a inversão das falhas extensionais da fase de abertura da bacia, fornecendo os ingredientes necessaries ao entendimento do significado tectonico dos diversos dominios, bem como ao entendimento da formagao e posterior individualização do Maciço Pernambuco-Alagoas ao longo de zonas de cisalhamento regionais. As feições tectonicas da Faixa Sergipana sao tambem comuns a outras faixas mdveis do sistema orogenético Pan-Africano/Brasiliano e são compatíveis com a fragmentação e amalgamação do supercontinente Gondwana ao longo de zonas de fraqueza litosferica no Proterozóico.

INTRODUCTION The Sergipano Belt of NE Brazil is a triangle-shaped, highly deformed wedge lying between the São Francisco Craton to the south, and the PernambucoAlagoas Massif, which is part of the Borborema Province, a segment of continental crust transected by continental-scale ductile zones of high strain, such as the Patos and Pernambuco shear zones (Fig. 1; Almeida et al. 1981, Santos \& Brito Neves. 1984). The craton was consolidated in the end of the Paleoproterozoic and, nearby the Sergipano Belt, consists of granulites, gneiss, migmatites, and granites (Fig. 2; Mascarenhas et al. 1984, Teixeira \& Figueiredo 1991). The Province is a puzzle of Neoproterozoic belts and granite-gneiss blocks (Fig. 2) reworked since the Archean and/or created mostly in the Mesoproterozoic (Van Schmus et al. 1993,1995), perhaps a Neoproterozoic collage of terranes, some of them with polycyclic evolution (Jardim de Sá 1994).

The Sergipano Belt (Fig. 2) comprises six lithotectonic domains separated by the Itaporanga, São Miguel do Aleixo,
Belo Monte-Jeremoabo and Macurure faults (Davison \& Santos 1989), and cross-cut by the Phanerozoic SergipeAlagoas and Tucano-Jatoba sedimentary basins. The Est\&icia is a sedimentary domain deposited on the craton, the Vaza Barris is a meta(volcano)sedimentary domain deposited around the Itabaiana and Simão Dias domes, the Macurure' is a (meta)volcanosedimentary domain deposited around the Jirau do Ponciano dome. The latter domain, plus the Po90 Redondo domain of migmatites, the Marancó and Caninde domains mainly of igneous-derived rocks, form the northern part of the belt, which is bounded to the south by the São Miguel do Aleixo fault. The faults are high-angle thrusts associated with sinistral and dextral sense strike-parallel movement, respectively to the $\mathrm{E}$ and $\mathrm{W}$ of the Tucano-Jatoba basin (combining data in Davison \& Santos 1989; Santos et al. 1988; Jardim de Sá et al. 1986, D'el-Rey Silva 1992).

Following pioneer suggestions for its continuation in the African continent (Humphrey \& Allard 1968, Allard 1969, 

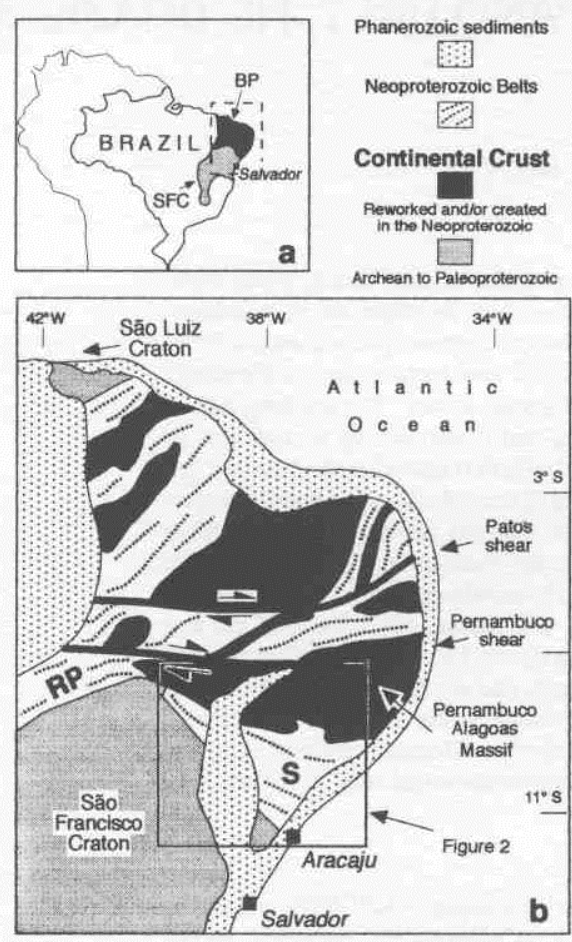

Figure 1: a - The São Francisco Craton (SFC) and the Borborema Province (BP) of NE Brazil, b - Simplified geological map of NE Brazil showing part of the São Francisco Craton, the Pernambuco-Alagoas Massif and several fold belts of the Borborema Province, including the Sergipano (S) - Riacho do Pontal/Rio Preto (RP) folding system. Based on Almeida et al. (1981) and Mascarenhas et al. (1984). Figura 1: a - O Craton Sao Francisco (SFC) e a Provmcia Borborema (BP), NE Brasil. b - Mapa geologico simplificado mostrando parte do Craton Sao Francisco, o Maciço Pernambuco-Alagoas e varias faixas dobradas da Provmcia Borborema, incluindo o sistema Sergipano (S) - Riacho do Pontal/Rio Preto (RP). Baseado em Almeida et al. (1981) e Mascarenhas et al. (1984).

Allard \& Hurst 1969), the Sergipano Belt is currently regarded as the central part of a megaorogen connecting the Oubangides Belt (or North Equatorial Belt) of Africa, with the Rio Preto Belt in Brazil (Davison \& Santos 1989, Trompette 1994) throughout the Riacho do Pontal Belt (Fig. Ib; Jardim de Sa et al. 1992, Jardim de Sá 1994). The megaorogen stretches for more than $2000 \mathrm{Km}$ and is a key element for global reconstructions whereby the northern margin of the São FranciscoCongo Craton faced a continuous ocean, the closure of which was part of the final amalgamation of western Gondwana about 500Ma ago (cf. Hoffman 1991, Dalziel 1992). Because the Sergipano Belt contains unique features such as mantled basement domes, it has strength to provide answers for questions on Proterozoic supercontinent cycle (D'el-Rey Silva 1994a).

This paper summarises the tectonic evolution of the Sergipano Belt with data from a PhD thesis based on a 1:50,000 scale geological mapping carried out in the area surrounding the Itabaiana and Simao Dias domes (D'el-Rey Silva 1992), plus data from a 1:100,000 scale geological mapping in the central part of the belt (Santos et al. 1988), and combined with a comprehensive survey in the more recent literature on the belt. The study area (Fig. 3) allowed to investigate the relationships across the Estancia, Vaza B arris and Macurure domains and contains the best preserved basement-cover relationships in the belt, as it encloses good-quality, almost continuous outcrops along streams and rivers cutting across the borders of the domes.

REGIONAL SETTING The cratonic Estancia domain is an undeformed to weakly deformed, $1-3 \mathrm{~km}$ thick blanket of continental to shallow marine siliciclastic and carbonate sediments divided in the Estancia and Simao Dias Groups. The miogeocline Vaza Barris domain is a 1 to $\geq 4 \mathrm{~km}$ thick wedge of sub-greenschist facies and highly deformed continental to platformal marine siliciclastic and carbonate sediments and volcanic rocks divided in the Miaba, Simao Dias and Vaza Barris Groups (Fig.2; D'el-Rey Silva 1992, D'el-Rey Silva \& McClay 1995).

In the northern part of the belt, the Macurure domain is a $\geq 13 \mathrm{~km}$ thick wedge of highly deformed, greenschist-amphibolite facies siliciclastic and carbonate metasediments, and metavolcanics of the Macurure Group, this one spreading away from the Jirau do Ponciano gneiss dome, around which have been characterised anatexis and kyanite-bearing assemblages of intermediate pressures (Jardim de Sá et al. 1981; da Silva 1993). This domain encloses a small graben filled with undeformed and nonmetamorphosed conglomerates, greywackes, and arkoses (the Jua Formation, Fig.2; Silva Filho et al. 1978a; Santos et al. 1988), and also surrounds the Poço Redondo migmatites, the Marancó acid-intermediary metavolcanics and siliciclastic metasediments, and the Caninde domain. The latter consists of basic-ultrabasic intrusive rocks and metavolcanics displaying an island arc geochemical signature (Blais et al. 1989; Bezerra et al. 1990) and hosted in an interlayered sequence of marbles, iron formation, garnet-mica schists, amphibolites (Silva Filho 1976). A suite of syn- to post-tectonic calc-alkaline granites (partially shown in Fig. 2) intrudes all the northern domains and also the PernambucoAlagoas Massif (Giuliani \& Santos 1988; Fujimori 1989; da Silva Filho et al. 1992).

Polydeformation and metamorphism resulted in an ESEWNW thrust-fold structural grain dominated by top to SSW movement, locally to NNE or NNW as in the northeastern part of the belt (Brito Neves et al. 1977, Jardim de Sa et al. 1981, 1986, Campos Neto\&Brito Neves 1987, Amorim et al. 1992), although the related stretching lineations are sistematicaly oriented sub-parallel to the orogen (Fig. 2; cf. Jardim de Sa et al. 1986, Santos et al. 1988, Davison \& Santos 1989, D'el-Rey Silva 1992, Amorim et al. 1992), except in parts of the Jirau do Ponciano dome (Amorim et al. 1993).

The Simão Dias gneiss dome displays a whole rock $\mathrm{Rb}-\mathrm{Sr}$ $2505 \mathrm{Ma}$ age (Humphrey \& Allard 1969), and orthogneisses of the Jirau do Ponciano dome display a whole rock $2500 \mathrm{Ma}$ $\mathrm{Rb}-\mathrm{Sr}$ age (Amorim et al. 1993). The São Francisco Craton and the Pernambuco-Alagoas Massif yield whole rock $\mathrm{Rb}-\mathrm{Sr}$ ages around $1800 \mathrm{Ma}$, in localities close to the belt margin (Mascarenhas et al. 1984), whereas the fold belt itself records a $1.0+/-0.1 \mathrm{Ga}$ old sedimentation [U-Pb data from Macurure domain metavolcanics, Brito Neves et al. (1993)] and a Rb-Sr 673-600Ma old structural-metamorphic evolution (Brito Neves \& Cordani 1973) also suported by Rb-Sr ages in some granites of the Macurure domain (Chaves 1991).

Santos et al. (1988) and Davison \& Santos (1989), who firstly characterised the six lithotectonic domains, interpreted the Sergipano Belt as a collage of allochtonous terranes. Before them, Humphrey and Allard (1968) and Silva Filho et al. $(1978 \mathrm{a}, \mathrm{b})$ argued for the lateral continuity between the 


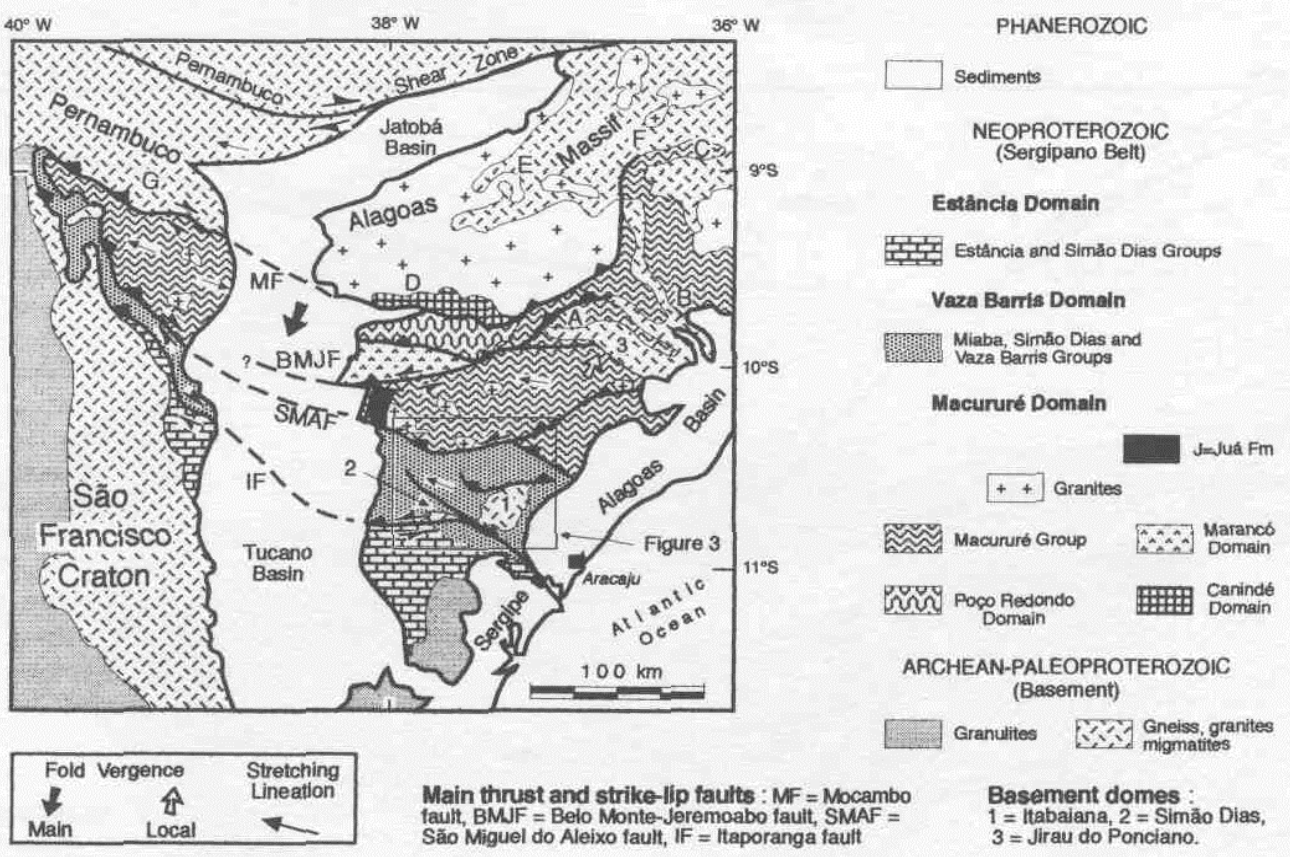

Figure 2: Simplified geological map of the Sergipano Belt and surroundings. Modified from Davison \& Santos (1989) and D'el-Rey Silva (1992). A-G stand for areas understudy (Amorim \& Torres 1994). Granites do occur in the Pernambuco-Alagoas Massif too. See text.

Figura 2: Sumario geológico da Faixa Sergipana e arredores. Modificado de Davison \& Santos (1989) e D'el-Rey Silva (1992). Letras A-G representam locais de recente mapeamento geologico (Amorim \& Torres 1994). Granites também ocorrem no Maciço Pernambuco-Alagoas. Detalhes no texto.

cratonic, miogeoclinal and eugeoclinal domains, and were followed by many authors. D'el-Rey Silva $(1992,1995)$ presented detailed and abundant evidence for a lithostructural continuity across these three domain boundaries.

The far northern part of the belt, including the Jirau do Ponciano dome and parts of the Pernambuco Alagoas Massif, is being mapped under 1:250,000 scale. To date, the results indicate: a- the Jirau do Ponciano dome consists of a Neoarchaean-Paleoproterozoic metavolcano-sedimentary sequence intruded by tonalite-granodiorite orthogneiss, which in turn are intruded by 2,000 Ma metagranites, the whole set being also strongly deformed in the Brasiliano cycle (Amorim et al. 1993); b- parts of the Macurure and Caninde domains, and also part of the Pernambuco-Alagoas Massif, all enclose small and irregular outcrop areas of a layered sequence (around localities A-G, Fig. 2) comprising high metamorphic grade amphibolites, metacherts, banded iron formation and metacarbonates (Amorim \& Torres 1994, J.L. Amorim, written communication 1995). These data are integrated in the model of tectonic evolution presented herein.

GEOLOGY OF THE ITABAIANA-CARIRA AREA Introduction The Itabaiana-Carira area (Fig. 3) includes part of the Macurure domain, the main part of the Vaza Barris domain, and part of the Estancia domain. The SergipeAlagoas Mesozoic Basin (not included in this study) occupies the southeastern corner of the area. The Itabaiana dome is an elliptical structure around the town of Itabaiana. The Simao Dias dome is the outcropping western end of a WNW-ESE trending, steeply-dipping tectonic slice stretching for about $150 \mathrm{~km}$. It crops out from the Atlantic coast (outside, to the E of the map area) along the trace of the Itaporanga fault, and continues to the $\mathrm{W}$, below the metasediments outside the map area, reaching the Tucano basin (gravity data in D'el-Rey Silva 1992, 1995).
Subvertical thrust, strike-slip and normal faults, together with some major south vergent $F_{2}$ folds, are the main mappable structures (Fig. 3). Main faults are the Jacaré, Itaporanga, Simao Dias, Escarpa, Pelada, Mocambo, Ribeiropolis, Dores, and Sao Miguel do Aleixo faults. Main strike-slip faults are the Vaza Barris fault and the Mocambo shear. Minor, subvertical, dextral and sinistral, NW-SE to E-W striking brittleductile shear zones cut across the eastern and southern margins of the Itabaiana dome. Major folds are those mapped in the western side of the Itabaiana dome and other folds part of the Paripiranga anticline. The latter affects a $F_{1}$ nappe responsible for a major stratigraphic inversion, to the west of the Simao Dias dome. Two overturned FI folds are interpreted within the narrow strip between the Ribeiropolis and Pelada faults (Fig.3; D'el-Rey Silva 1992).

Stratigraphy The Neoproterozoic (volcano) sedimentary wedge of the area is divided into the Estancia and Simao Dias groups, in the cratonic domain, the Miaba, Simao Dias and Vaza Barris groups, in the miogeocline domain, and the Macururé Group, in the eugeoclinal domain (legend of Fig. 3). The Estancia and Miaba groups are both deposited on the crystalline basement and form the base of the column as correlative units. The Simao Dias Group overlies both these groups and is continuous across the cratonic-miogeocline domain boundary, whereas the Vaza Barris Group occurs only to the north of the Itaporanga fault. All these groups are laterally correlated to the pelitic schists and marbles of the Macurure Group (D'el-Rey Silva 1992,1993,1995, D'el-Rey Silva \&McClay 1995)

The crystalline basement domes consist of amphibolite grade, granitic to granodioritic, generally well banded gneiss and orthogneiss, locally intruded by sheet-like basicultrabasic rocks and granites, together with derived mylonitic rocks, all retrometamorphosed to the greenschist facies. 

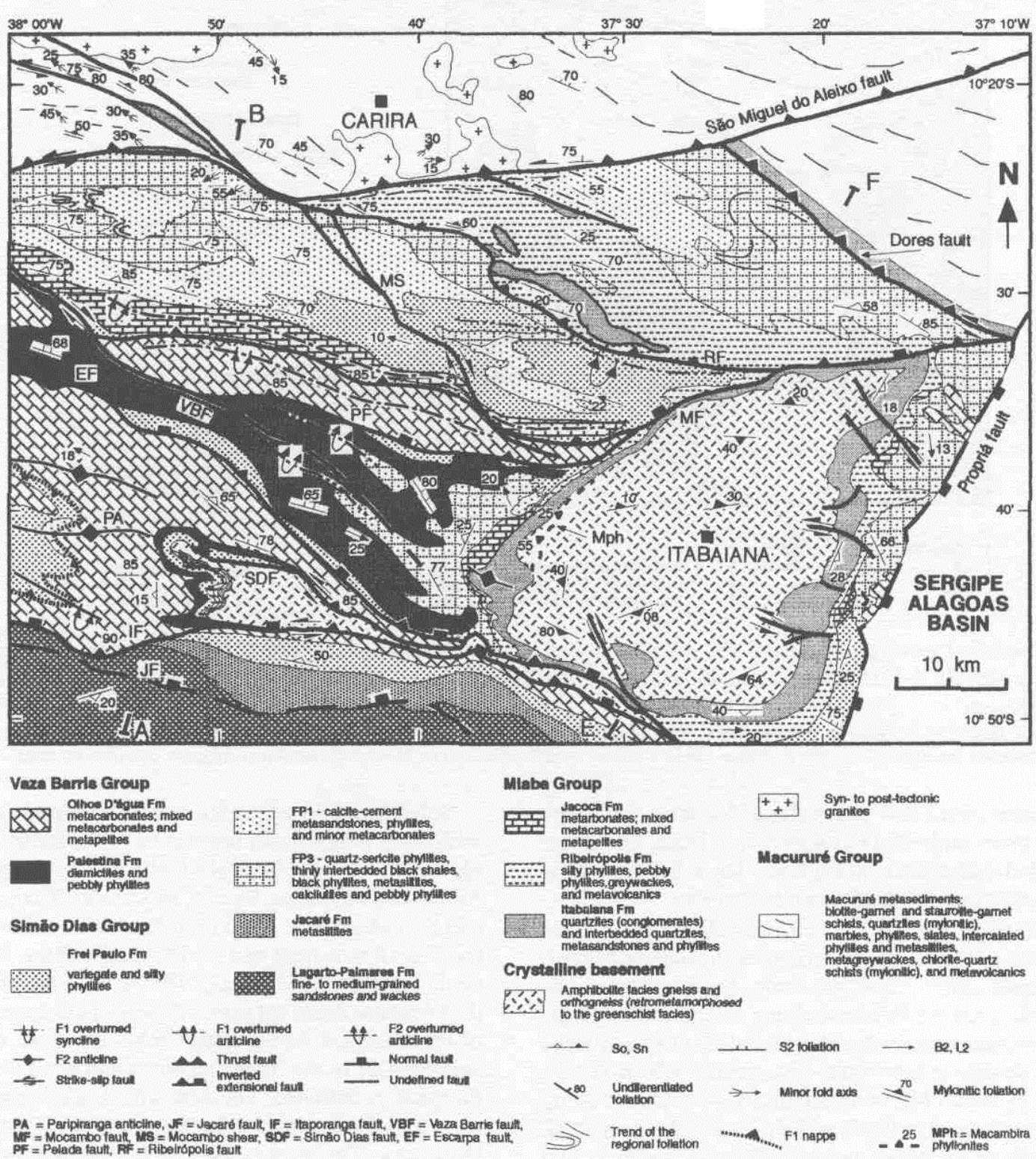

Figure 3: Summary geological map of the Itabaiana-Carira Area. Sediments of the Mesozoic Sergipe-Alagoas Basin are omited from the legend for simplicity. AB and EF are the structural cross sections lines of Figure 4. $x, y, z$, and $w$ are particular outcrops described in the text. From D'el-Rey Silva (1992).

Figura 3: Mapa geológico sumário da região Itabaiana-Carira. Por simplificação, foram omitidos os sedimentos da bacia Mesozóica Sergipe-Alagoas na legenda. AB e EF sao as linhas das seções verticais da Figura 4. x, y, z, e w são afloramentos especiais descritos no texto. Segundo D'el-Rey Silva (1992). Detalhes no texto.

Gneiss and orthogneiss are composed of coarse-grained quartz, plagioclase, and K-feldspars, biotite (hornblende), muscovite, sericite, chlorite and epidote. Accessories are apatite, sphene, zircon, and opaque minerals. Garnet occurs locally. These rocks are generally well banded or occur as basement-derived S-C mylonites generally consisting of a $\mathrm{mm}$ fine-grained matrix and mm-size porphyroclasts of $\mathrm{K}$-feldpars, plagioclase, and epidote. The matrix consists of recrystallised quartz and feldspars grains with a preferred planarparallel orientation cross-cut by planes defined by extremely fine grained quartz, epidote, sericite, chlorite, and biotite. The amphibolite grade banding and the mylonitic foliation are the reference planes $(\mathrm{Sn})$ in the basement for deformational analysis in the area.

The basement-cover contact dips at low-angles around the northern, eastern, and western margins of the Itabaiana dome and in the western side of the Simao Dias dome, but dips at high-angles in the rest of the area. Rocks on both sides of the contact are generally sheared, except in parts of the eastern margins of the Itabaiana dome, and locally on the western margin of the Simao Dias dome, where undeformed basal conglomeratic lithofacies of the Itabaiana Formation rest unconformably on basement gneiss isoclinally folded (Davison \& Santos 1989; D'el-Rey Silva 1992, 1995).

Of particular interest are the contact relationships on the western margin of the Itabaiana dome, where the Itabaiana quartzites are sheared and occur directly above basementderived quartz-feldspar-sericite-chlorite phyllonites displaying a sinusoidal map pattern (Fig. 3; the Macambira phyllonites of Humphrey and Allard 1969). Detailed mapping showed that the phyllonites are mostly derived from basic rocks intruded within the gneiss, dip $20^{\circ}-55^{\circ}$ to the WNW 
(Fig. 3) and are affected by an anastomosed set of finely spaced extensional shear bands dipping $25^{\circ}-50^{\circ}$ to $\mathrm{WNW}$, indicative of a top down to WNW extension affecting the western part of the dome and its quartzitic cover (D'el-Rey Silva 1992, 1995).

The Estância Group unconformably overlies the crystalline basement and is subdivided in the Juete and Acaua formations. The $\leq 100 \mathrm{~m}$ thick Jueté Formation consists of massive or laminated arkosic sandstones, with conglomeratic lenses of basement derived clasts, and brown to red argillites. The upper section is marked by red brown to purple, fine to medium grained feldspathic sandstones with clasts of red argillites (Saes 1984, Silva Filho 1982). The $\leq 300 \mathrm{~m}$ thick Acauã Formation conformably overlies the-Juete Formation and unconformably overlies the basement gneiss. It consists of limestones, dolomites and calcitic argillites with lenses of limestones, overlain by limestones and dolomites with thin intercalations of fine-grained, cross-bedded, red sandstones and green argillites. These rocks are blanketed by $700-2000 \mathrm{~m}$ of arkoses and lithic sandstones (the Palmares sandstones, Silva Filho 1982, Saes 1984) incorporated in the siliciclastic Lagarto-Palmares Formation (D'el-Rey Silva 1992), described ahead.

The Miaba Group is $\approx 1100 \mathrm{~m}$ thick, unconformably overlies the Itabaiana and Simao Dias basement domes, and comprises the Itabaiana, Ribeiropolis and Jacoca Formations. The Itabaiana Formation is $\approx 400-700 \mathrm{~m}$ thick in the southern, eastern and western sides of the Itabaiana dome, and consist of (discontinuous, basal conglomerates) medium- to finegrained, cross-bedded feldspathic quartzites that passes gradually up section into grey to red brown metasiltites and meta-argillites. These contain $\approx 10 \mathrm{~m}$ thick lenses of matrixsupported conglomerates and conglomeratic sandstones, with basement-derived clasts, particularly in the eastern and western sides of the Itabaiana dome. Elsewhere this formation is $\approx 10 \mathrm{~m}-50 \mathrm{~m}$ thick and generally consists of muddy, micaceous quartzites and/or arkosic sandstones intercalated with red brown phyllites. The Ribeiropolis Formation varies from $\mathrm{Om}$ to $\approx 100 \mathrm{~m}$ up to $\geq 500 \mathrm{~m}$ thickness, conformably overlies the Itabaiana quartzites, and consists of light to red brown silty phyllites with intercalations of metagreywackes, pebbly phyllites, argillites and (weathered) acid/intermediary to basic metavolcanics. It may consists of thin bodies of conglomerates with clasts of the underlying rocks (western margin of the Itabaiana dome) or highly foliated black-dark brown metavolcanics (western margin of the Simao Dias dome). Up to Im-size clasts of gneiss have been described in outcrops of diamictites along the northeastern margin of the Itabaiana dome (cf. Humphrey and Allard 1969) in a stream very close to the trace of the Mocambo fault. The Jacoca Formation occurs as $\approx 100-300$ m thick discontinuous bodies around the Itabaiana dome (Fig. 3) and consists of light grey metadolomites passing to thinly intercalated metadolomites, metachert and black calci-phyllites, metre-thick metadolomites thinly intercalated with metacalcilutites, metacalcarenites and black and locally carbonaceous phyllites. The upper succession consists of $\leq \mathrm{lm}$ thick layers of metadolomites. Elsewhere (Fig. 3) this formation consists of a $\leq 300 \mathrm{~m}$ thick sequence of $\leq 10 \mathrm{~m}$ thick lenses of metadolomites intercalated with light brown phyllites (Simao Dias dome), or Im-thick layers of black, fine-grained metalimestones intercalated with $\approx 10 \mathrm{~cm}$ thick variegated metapelites (north of the Mocambo fault).
The Simão Dias Group is a new lithostratigraphic unit identified in the southern part of the Sergipano Belt and comprising the interfingered Lagarto-Palmares, Jacare and Frei Paulo Formations. Far into the craton, the Simao Dias Group is represented by the $\approx 700-2500$ m thick LagartoPalmares Formation. The entire group is seen in the core of the Paripiranga anticline, to the $\mathrm{W}$ of the Simao Dias dome, and to the $\mathrm{S}$ and $\mathrm{E}$ of the Itabaiana dome (Fig. 3). In the Itabaiana-Carira area the Lagarto-Palmares Formation (D'el-Rey Silva 1992) is a $\leq 700 \mathrm{~m}$ thick coarsening-upwards sequence of mudstones, siltstones, fine- and medium-grained calcite-cemented sandstones, and lithic wackes which spreads on the craton and on the southern part of the area (Fig. 3). It stands for the Lagarto and Palmares Formations described in gradual passage by Saes (1984), in the cratonic domain. There, the basal Lagarto sandstones have detrital, carbonate grains and the contact with the Palmares Formation is gradual and interfingered, although enclosing local carbonate breccia and lenses of conglomerates with clasts of carbonates and basement-derived high and low metamorphic grade rocks. The Jacare Formation (D'el-Rey Silva 1992) accounts for an E-W trending strip of light brown, micaceous and massive or thinly laminated, light brown to variegated metasiltites (with lensoid bodies of fine- to medium-grain, light brown metasandstones), mapped between the typical Lagarto-Palmares sandstones and Frei Paulo phyllites (Fig. 3). The Frei Paulo Formation is $\approx 100 \mathrm{~m}$ up to $\geq 500 \mathrm{~m}$ thick and consists of light grey to brown or variegated silty phyllites with intercalations of metasandstones and wackes, both to the south of the Escarpa fault and to the north of the Mocambo fault. In this latter area it contains important lenses of calcite-cemented lithic wackes with the same petrographic characteristics of the Lagarto-Palmares sandstones (lithofacies FP1; Fig. 3). In the area between the Escarpa and Pelada faults, and also to the east of the Itabaiana dome, the dominant lithofacies (FP3) includes green-grey, quartz-sericite-chlorite phyllites, thinly interbedded metagreywackes and metalimestones, metarhythmites, minor metasandstones, together with local lenses of highly weathered metavolcanics. The formation also occurs in the stratigraphic inversion to the west of the Simao Dias dome (Fig. 3), and consists of sandy phyllites with intercalations of metasandstones, displaying a strong layer-parallel $\mathrm{Si}$ foliation very close to the basal contact with Olhos D'agua Formation metacarbonates.

The Vaza Barris Group is $\geq 2000 \mathrm{~m}$ thick and comprises the Palestina and Olhos D' água formations that unconformaby overlye the Simão Dias Group (Fig. 3). The Palestina Formation consists of diamictites and pebbly phyllites, minor phyllites, and $\leq 10 \mathrm{~m}$ thick lenses of coarse-grained, ironcemented quartzites. The diamictites contain clasts of basement rocks, quartzites, phyllites and metacarbonates, supported in a green grey, extremely foliated quartz-sericitic matrix. The thickest sections $(\geq 500 \mathrm{~m}$ ?) are between the Escarpa and Pelada faults, where the matrix is finer and the $>10 \mathrm{~cm}$ size clasts are abundant. Around the Simao Dias dome it is $\approx 10-100 \mathrm{~m}$ thick, the matrix may be siltier and $\geq 10 \mathrm{~cm}$ clasts are generally rare, despite of a 4m-long block of gneiss found in a large outcrop near the western end of the trace of the Simao Dias fault. East of the Itabaiana dome the diamictites are barely mappable (Fig. 3), but contain boulders of Itabaiana quartzite and Lagarto-Palmares metasandstones which have not been found elsewhere, nor described in the previous literature of the area (D'el-Rey Silva 1992). The 
Olhos D'agua Formation is $\approx 200 \mathrm{~m}$ up to $\geq 1300 \mathrm{~m}$ thick and mostly occurs around the Simao Dias dome, to the east of the Itabaiana dome and to the north of the Pelada fault (Fig. 3). The typical section (from the Simão Dias dome to NNW) comprises a basal unit of 100's metres of thinly interbedded, light grey to black, fine-grained metalimestones with minor intercalations of metasiltites, meta-argillites and metachert, which passes to 100 's $\mathrm{m}$ of interbedded, oolitic, pelloidal, black metalimestones with intercalations of brown metapelites, and metre-thick layers of grey, cross-bedded and wavereworked metadolarenites. Approaching the Escarpa fault this unit passes gradually into a sequence of 100's metres of $10-100 \mathrm{~cm}$ thick layers of fine-grained, black metalimestones intercalated with $\approx 10 \mathrm{~cm}$ thick layers of red. brown pyritic metapelites.

The Macurure Group consists mostly of biotite- and staurolite-garnet schists, chlorite-quartz schists, metacarbonates, phyllites, metasiltites, metagreywackes, mylonitic quartzites and intermediary metavolcanics intruded by granite-granodiorite bodies (Silva Filho et al. 1978 a,b; Santos et al. 1988).

\section{Megasequence stratigraphy and basin geometry}

According to D'el-Rey Silva (1992), D'el-Rey Silva and McClay (1995), the lithologic record of the southern part of the Segipano Belt may be divided in two sedimentary cycles, each one formed by a siliciclastic and a carbonate megasequences. Cycle I holds a lower siliciclastic megasequence (the Juete-Itabaiana and Ribeiropolis Formations) and a lower carbonate megasequence (the Acaua-Jacoca Formations). Cycle II holds an upper siliciclastic megasequence (the Simao Dias Group and Palestina Formation) and an upper carbonate megasequence (the Olhos D'água Formation). The lithofacies and thickness distribution of the metasediments throughout the Itabaiana/Carira area allows to conclude that the sedimentation records tectonically controlled sedimentation whereby a continental to shallow marine environment developed, and the original basin had a paleogeography dominated by basement paleohighs (the precursors of the Itabaiana and Simao Dias domes) and by a WNW-ESE trending, $\approx 300 \mathrm{~km}$ long trench. This trench, which is bounded by the Escarpa and Pelada faults, received relatively deeper-water rocks of the Jacoca and Frei Paulo formation, and the Palestina diamictites. The data strongly suggest that most of the regional faults in the southern part of the Sergipano Belt are original normal faults positively inverted (Fig. 4). The diamictites formations probably record gravitational instability and dominance of mass flow processes, whereas the carbonate formations probably record a relative tectonic quiescence in the basin following the deposition of each siliciclastic megasequence. The precursor Sergipano basin was probably asymmetric, shallower to the $\mathrm{W}$, deeper to the $\mathrm{E}$ and to the $\mathrm{N}$, possibly recording an event of oblique extension of the craton margins.

Structures Three main deformational events $\left(D_{1}-D_{3}\right)$ affected the sedimentary cover and the gneiss basement of the southern part of the belt. These events are distinguished on the basis of refolded folds and overprinting relationships of folds and foliations. The superposition of $D_{1}$ and $D_{2}$ events on mechanically different rocks resulted in structural partitioning in the area, and six structural domains have been defined, on the basis of different styles of the $F_{2}$ folds, the relative attitude of $S_{1}$ and $S_{2}$ and also the nature of the $S_{2}$ foliation, together with variations in the trends of $\mathrm{S}_{2}$ and $\mathrm{L}_{2}$ (D'el-Rey Silva 1992).

The cratonic domain is to the $\mathrm{S}$ of the Itaporanga fault and comprises mostly flat-lying sediments locally affected by gentle folds; the Simao Dias and Itabaiana domains consist of highly deformed gneiss of the two basement domes; the regional domain comprises the metasediments outside of the dome and spreads over the rest of the Itabaiana-Carira area, northward of the Itaporanga fault. The east and west domains are on both sides of the Itabaiana dome, very close to the dome margin, and correspond to metasediments which structures have a particular orientation relative to the regional domain (Fig. 3). Details are given ahead in this paper.

The $\mathbf{D}_{1}$ Deformation is characterised by folding, thrusting and by a pervasive foliation. The $\mathbf{F}_{\mathbf{1}}$ folds range in size from 10 's of centimetres to 10 's of metres, are generally rootless, and have their overturned limbs transposed by subhorizontal thrusts. These folds are WNW-ESE trending, SSW verging, isoclinal and recumbent folds that affect the sedimentary bedding $\left(\mathrm{S}_{0}\right)$ and the basement metamorphic banding $\left(\mathrm{S}_{\mathrm{n}}\right)$ and develop a strong axial planar foliation (Si) better seen in carbonate rocks and in poly folded phyllites. Good examples of Fi folds and thrusts are in the Jacoca Formation of the largest outcrop of the belt (the Capitão farm outcrop detailed ahead in this paper), and in the Acauã carbonates in the cratonic area of the western part of the belt (Jardim de Sa et al. 1986).

$\mathbf{S}_{\mathbf{1}}$ is mainly a mineral foliation and a slaty cleavage. The former is defined in thin sections by planar-parallel oriented sericite, muscovite, biotite, chlorite, and flattened, very fine grained quartz (also feldspars and epidote substituting for hornblende in the basement rocks). The latter consists of finely spaced partition planes in phyllitic rocks. Thin quartz and carbonate veins are observed sub-parallel to $S_{1}$, increasing in intensity to the $\mathrm{N}$ of the Itabaiana dome. $\mathrm{S}_{1}$ is generally sub-parallel to $S_{0}$ or $S_{n}$, and the attitude of the whole set is WNW-ESE with dips of $90^{\circ}-60^{\circ}$ to the NNE (regional and Simao Dias domains), or $60^{\circ}-50^{\circ}$ to NNE (Itabaiana domain). Atitudes varying from $20^{\circ} / 318^{\circ}$ to $60^{\circ} / 033^{\circ}$ and from $30^{\circ} / 046^{\circ}$ to $15^{\circ} / 130^{\circ}$ characterise the west and east domains, respectively (Fig. 5a).

$\mathbf{L}_{1}$ linear features are the fold axes $\left(\mathbf{B}_{1}\right)$, the intersection lineation $\left(\mathrm{L}_{1}-0\right)$ and a mineral lineation (oriented flakes of micaceous minerals, ribbons of quartz and feldspars). The few observed examples plunge gently to WNW or ESE.

The $\mathbf{D}_{2}$ Deformation comprises a set of structures comparable to $\mathbf{D}_{\mathbf{1}}$ plus a penetrative stretching lineation. The $\mathbf{F}_{\mathbf{2}}$ folds are WNW-ESE trending, open to isoclinal, gently inclined to upright, generally SSW verging and gently plunging folds (Fig. 6a). They co-axially refold the $\mathrm{D}_{1}$ structures, range in size from micro crenulations to $\mathrm{km}$-scale (observed in aerial photographs) and develop a penetrative axial planar foliation $\left(\mathrm{S}_{2}\right)$.

$\mathbf{S}_{\mathbf{2}}$ dips $60^{\circ}-90^{\circ}$ to NNE in the regional, Simao Dias and Itabaiana domains, and to NE in the west and east domains (Fig. 5b). It is a pressure solution (Fig. 6b) or a mineral foliation, but may consist of a spaced cleavage in more competent rocks. In thin sections the pressure solution cleavage is normally defined by iron or manganese oxide seams, and in phyllitic rocks it is marked by very fine sericite and chlorite (minor biotite) flakes, resembling the discrete crenulation cleavage of Gray (1977). The mineral foliation is also marked 

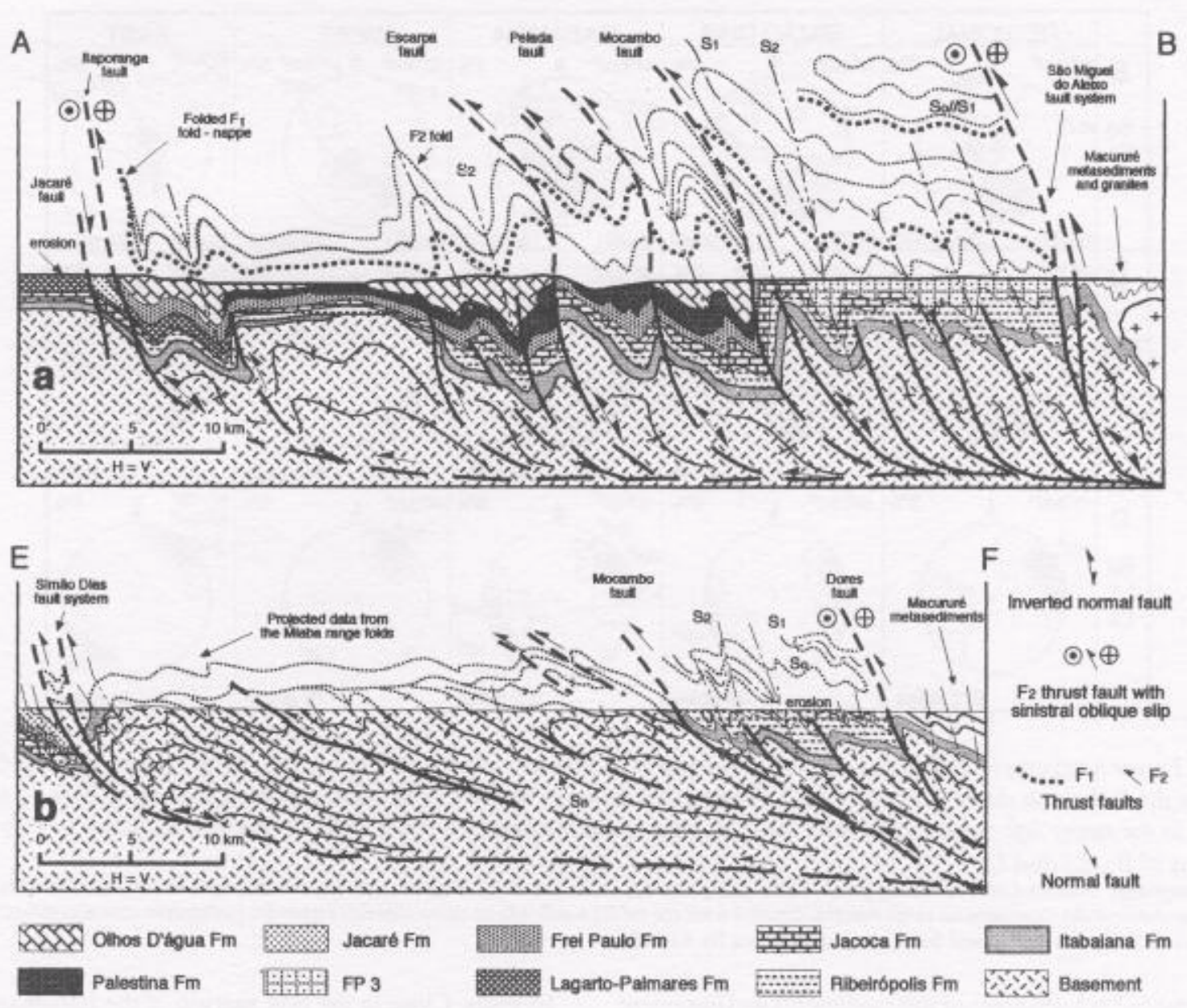

Figure 4: Vertical cross sections AB and EF (respectively a and b) as indicated in Figure 3. From D'el-Rey Silva (1992). See text.

Figura 4: Secoes verticals AB e EF (respectivamente a e b) como indicadas na Figura 3. Segundo D'el-Rey Silva (1992). Detalhes no texto.

by parallel flakes of these minerals, as well as very fine grained quartz and feldspars in diamictite and gneiss.

$\mathbf{L}_{2}$ linear features (Fig. 5c) are the fold axis (62), the intersection lineation (Li-2) and the stretching lineation (Ls), all parallel to each other and plunging in average $08^{\circ}-16^{\circ}$, either to the WNW or ESE - in the regional, Simao Dias and Itabaiana domains - or to the NNW or SSE in the west and east domains, confirming the change of the strike of 82 in these domains relative to the other. $\mathbf{L}_{\mathbf{1 - 2}}$ is rather strong and may consist of an intense, pencil-like lineation extremely similar in several outcrops of metasediments and basement rocks (Fig. $6 c)$. Ls is defined by flattened and elongated oolites and pellets in metacarbonates; by pyrite and fine-grained quartz in phyllites; pulled-apart grains of K-feldspar, plagioclase and clasts of basement rocks in diamictite and pebbly phyllite; ribbons of quartz, trains of deformed opaque minerals and pressure shadow zones developed around K-feldspar or tourmaline clasts in quartzite (Fig. 6d); quartz ribbons, trains of elongated feldspars, and aligned grains of epidote or pulled-apart grains of K-feldspars and hornblende (these ones with needles of actnolite/tremolite infilling the pressure voids) in gneiss and basement derived mylonites.

\section{The regional faults and vertical cross-sections}

The regional faults have a clear signature in aerial photographs and aeromagnetic maps, and in the field the fault zones nor- mally correspond to mylonitisation and intense $\mathrm{F}_{2}$ folding of the country rocks, with the mylonitic foliation generally dipping at high angles or sub-vertically to the NNE (Fig. 3; D'el-Rey Silva 1992). Indicators such as S-C relationships (Lister \& Snoke 1984, Shimamoto 1989), porphyroblast-tail systems (Passchier \& Simpson 1986), extensional shear bands (Plat \& Vissers 1980, Passchier 1984), and a penetrative stretching lineation, best seen along the Simão Dias, Itaporanga and Dores faults, all indicate top to the south kinematics, combined with E-W strike-parallel slip.

The regional $\mathrm{F}_{2}$ folds and the folds inside the fault zones have compatible mineral assemblages along their axial planar foliations and have similar orientation of the axial planes, axial planar foliations, fold axes, intersection and mylonitic lineations. The regional faults are probably zones of high strain during $\mathrm{D}_{2}$ event and the latest strike-slip movement post-dates the regional metamorphism, as indicated by the $\mathrm{D}_{3}$ structures, and as interpreted for the Sao Miguel do Aleixo fault by Davison \& Santos (1989).

The structural pattern in vertical cross-sections through the Simao Dias and Itabaiana basement domes (Fig. 4a-b) is that of large-scale $F_{1}$ folds -perhaps nappes associated with subhorizontal thrusts -refolded by $\mathrm{F}_{2}$ folds to form a classical type 3 -coaxial interference pattern (Ramsay 1967) subsequently disrupted and uplifted by reverse faults, mostly corresponding to positively inverted extensional faults. The cross sections 


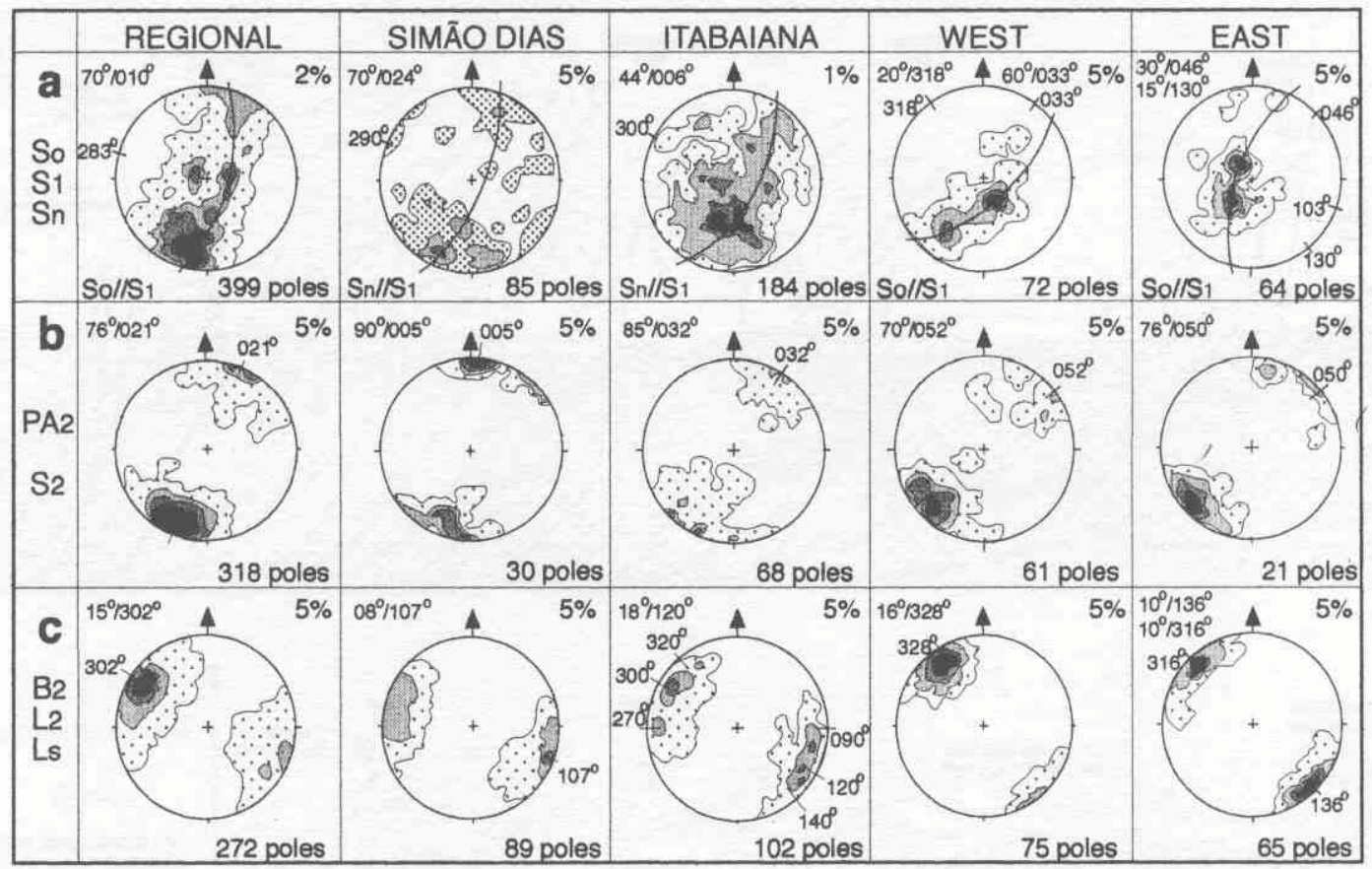

Figure 5: Lower hemisphere, Schmidt-Lambert stereograms to show the plot of the $D_{1}-D_{2}$ structural elements for each structural domain in the Itabaiana dome area. For each diagram the contour intervals are shown in the upper right corner, the average atitude is in the upper left corner as well as the atitude(s) of the maxima, a-poles to $S_{0}, S_{1}$ and $S_{n} ; b$ - poles to P $A_{2}$ and $S_{2}$. c $n$ diagrams of $\mathrm{B}_{2}, L_{2}$ and $L_{s}$.

Figura 5: Diagramas Schmidt-Lambert (hemisferio inferior) dos polos das estruturas de $\mathrm{D}_{1}-\mathrm{D}_{2}$ para cada um dos domfnios estruturais. Em cada diagrama, os intervalos de contorno sao mostrados no canto superior direito e a atitude media e indicada no canto superior esquerdo, juntamente com a(s) maxima(s). a - polos de $\mathrm{S}_{\mathrm{o}}, \mathrm{S}_{1}$ and $\mathrm{S}_{\mathrm{n}} ; \mathrm{b}$ - polos de $\mathrm{PA}_{2}$ and $\mathrm{S}_{2}$. c - diagramas $\pi$ para $\mathrm{B}_{2}, \mathrm{~L}_{2}$ and $\mathrm{L}_{\mathrm{s}}$.

show a balance between areas of metasediments and basement which has been validated by interpretations of gravimetric and aeromagnetic data in the Itabaiana-Carira area. Although the representation of the structures above the erosion line must be taken as a cartoon illustration, the folded $F_{1}$ nappe interpretation (Fig. 4a) accounts for the stratigraphic repetition of the Frei Paulo Formation to the west of the Simao Dias dome and explains the lithostratigraphic interpretations across the area, particularly to the north of the Mocambo fault (Fig. 3; D'elRey Silva 1992). Moreover, the nearly $30 \mathrm{~km}$ of $F_{1}$ nappe displacement to the SSW (Fig. 4a) matches with the magnitude of other nappe descriptions elsewhere in the belt (Jardim de Sa et al. 1986; Campos Neto \& Brito Neves 1987).

The São Miguel do Aleixo fault is a $\geq \mathrm{lkm}$ wide sinistral mylonitic zone which last movements imprinted some sinistral rotation on the regional $\mathrm{S}_{2}$ foliation in the Macururé domain (Fig. 3). More detailed descriptions are in Santos et al. (1988) and Davison \& Santos (1989). The Dores fault places highly sheared quartzites and basement-derived phyllonites over Frei Paulo phyllites, as observed in a road-cut of the eastern corner of the area, where the $\leq 0.5 \mathrm{~m}$ thick fault zone is sub-vertical and is marked by percolation of manganese and iron oxides. The Ribeirópolis fault is interpreted on the basis of lithostratigraphic correlations whereby the Ribeiropolis Formation is structurally above the Frei Paulo Formation in the northern part of the area (Fig. 3). The Mocambo fault changes characteristics along the trace. In the northern margin of the Itabaiana dome, the fault is a $30 \mathrm{~m}$ wide zone of imbricated, metre-thick tectonic slices of weathered basement gneiss and mylonitic Itabaiana quartzites, all dipping $40^{\circ}-60^{\circ}$ to NNE and associated with asymmetrical, almost recumbent
$\mathrm{F}_{2}$ folds. Close to the NW margin of the Itabaiana dome, the fault zone is $<1 \mathrm{~km}$ wide zone of poorly exposed, intensely foliated and brecciated Frei Paulo metasandstones and phyllites.

The Pelada fault is marked by a $<1 \mathrm{~km}$ wide zone of intense quartz veining, stretching for $\geq 1 \mathrm{~km}$ to the west of the Itabaiana dome, and by a local zone of shearing in the Palestina diamictites, close to the NW limit of the area. The Escarpa fault places tightly folded Frei Paulo variegated phyllites on tightly folded and transposed Olhos D'água metacarbonates (Fig. 3). A road-cut for enlargement and pavement of a main road (1995; locality $\mathbf{x}$ in Fig. 3 ) shows $15 \mathrm{~m}$ along strike of the sub-vertical, $1 \mathrm{~m}$-wide fault zone which is marked by intense fluid percolation, through a complex array of quartz veining in the contact between the Olhos D'água and Frei Paulo formations. Few metres to the N, still within the Frei Paulo phyllites, there is a $\leq 50 \mathrm{~m}$ wide zone of sub-vertical Palestina diamictites and isoclinally folded, sub vertical and transposed Olhos D'água metacarbonates, suggesting fault imbrication in the hangingwall of the main fault. The Simão Dias fault is a $<2 \mathrm{~km}$ wide zone of imbricated steep-dipping slices of highly folded quartzite- and basement-derived mylonites and phyllonites, better exposed at the northern border of the Simao Dias dome. To the south of the Itabaiana dome, the Simão Dias fault is a $\approx 2 \mathrm{~km}$ wide zone of sub-vertically imbricated slices of tightly to isoclinally folded mylonitic Itabaiana quartzites, Ribeirópolis phyllites and gneiss (detailed in D'el-Rey Silva 1992, 1995), all exhibiting a strong pencil-like intersection lineation parallel to a mineral stretching lineation (e.g. Figs. 6c-d). 

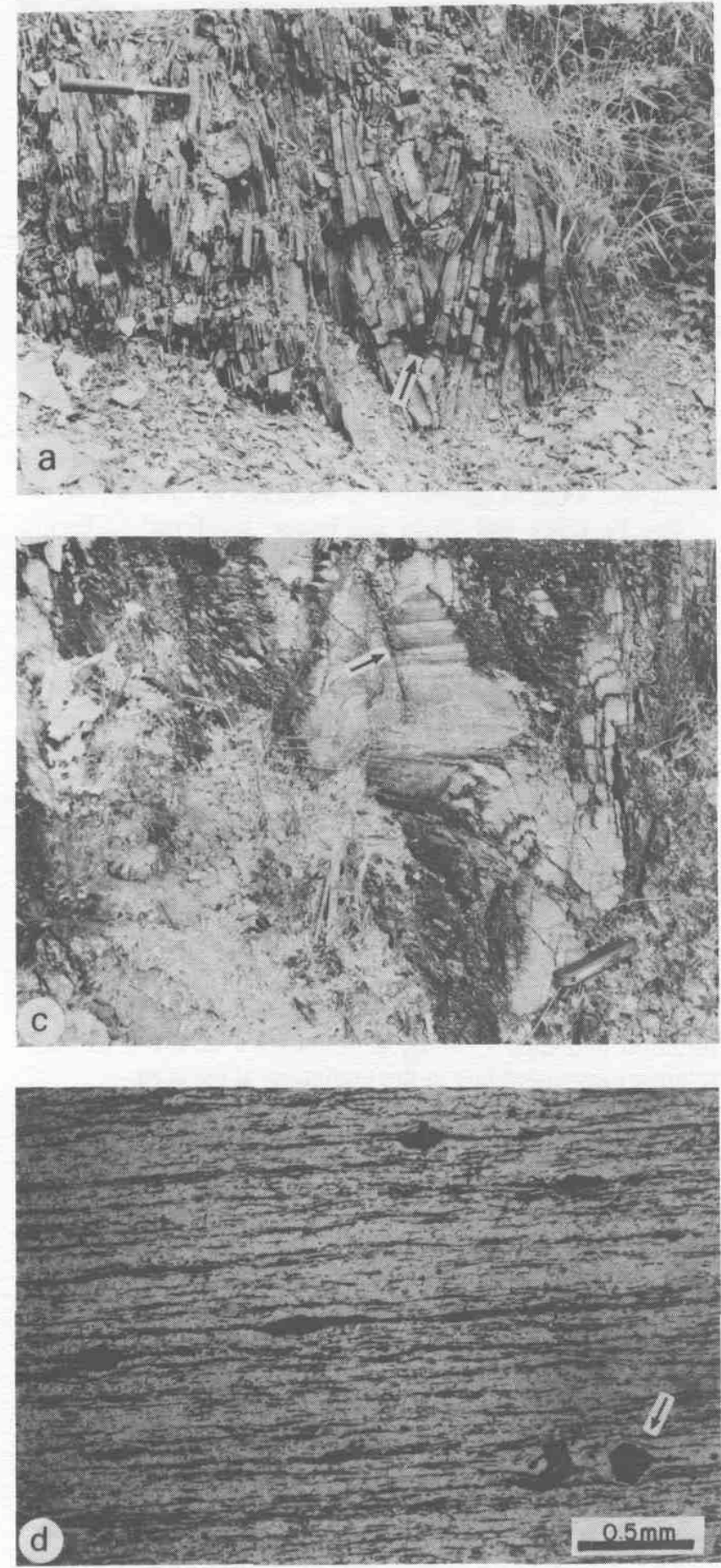

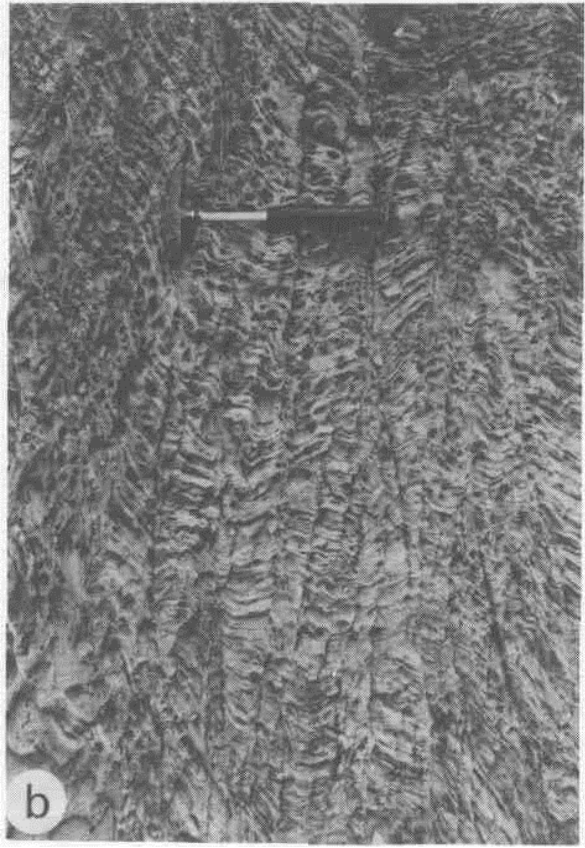

Figure 6: The $D_{2}$ deformation, a - Very tight, up-right, $F_{2}$ folds affecting Frei Paulo Formation distal turbidites in the northern mapped area. Note the fold hinge thickening (arrow), $b$ The $S_{2}$ foliation marked by subvertical and anastomosed surfaces of strong pressure solution cross-cutting finely laminated Olhos D'água metalimestones, in the $S W$ of the area, $c$ - $F_{2}$ folds affecting Basement-derived mylonites in the southern margin of the Itabaiana dome, and showing the pencil-like $L_{2}$ intersection lineation (arrow). $S_{2}$ dips at lower angle to NNE (right) than the average dip of the mylonitic foliation, exception for the hinge of the folds. In thin sections of this locality, the stretching lineation $\left(L_{s}\right)$ of the mylonites is parallel to $L_{2}$. Few meters to the left, outside of the photo but in the same outcrop, the mylonitic Itabaiana quartzites exhibit similar structural relationships, $d$ - Photograph under planepolarized light of a thin section perpendicular to $S_{2}$ and parallel to $L_{s}$, in the Itabaiana quartzites along the southern margin of the Itabaiana dome. $L_{s}$ is defined by ribbons of quartz, trains of opaque minerals and shadow zone tails around tourmaline crystals (arrow).

Figura 6: Deformação $\mathrm{D}_{2}$. a - Dobras $\mathrm{F}_{2}$ muito apertadas e normais, afetando turbiditos Frei Paulo na parte norte da area mapeada. A seta aponta as charneiras espessadas. $b$ - Foliação $S_{2}$ marcada por anastomose de superficies de intensa dissolucao por pressao desenvolvidas em calcarios Olhos D'água, na parte sul da area, $\mathrm{c}$ - Dobras $\mathrm{F}_{2}$ afetando milonitos do embasamento no contato sul do domo de Itabaiana e mostrando a lineação de intersecção tipo lápis (seta). Note que $S_{2}$ mergulha para NNE (direita) porem menos que a foliação dobrada, exceto nas charneiras. Laminas delgadas desta localidade

mostram a lineacao de estiramento $\left(L_{s}\right)$ dos milonitos paralela a $L_{2}$ Pouco metres a sul, fora da foto porem no mesmo afloramento, quartzitos miloniticos Itabaiana exibem relacoes estruturais equivalentes. $\mathrm{d}$ - Microfotografia sob luz paralela de lamina delgada perpendicular a $\mathrm{S}_{2}$ e paralela a $\mathrm{L}_{\mathrm{s}}$, em quartzitos Itabaiana miloniticos, na margem sul do domo de Itabaiana. $\mathrm{L}_{\mathrm{s}}$ e defmida por fitas de quartzo, trem de minerals opacos e zonas de pressao em torno de cristais de turmalina (seta).

The Itaporanga fault is a $\leq 500 \mathrm{~m}$ wide phyllonite-mylonite zone mostly affecting the Simao Dias gneiss and the Olhos D'agua metacarbonates (Fig. 3). In locality y of the SW part of the study area (Fig. 3), the fault plane dips $85^{\circ}$ to $356^{\circ}$ and contains a striae lineation plunging $24^{\circ}$ to $080^{\circ}$. It separates highly folded metacarbonates, to the $\mathrm{N}$, from sheared and silicified Lagarto-Palmares sandstones, to the $\mathrm{S}$, and is also marked by a well-cemented and badly stratified carbonate breccia, without sandstone clasts.
The Vaza Barris fault and the Mocambo shear, as well as the strike-slip faults of the eastern-southern border of the Itabaiana dome, are all observed in aerial photographs rotating the regional foliation and/or displacing contacts. Some kinematic indicators are seen in the field, as dextral shear zones affecting the $S_{2}$ foliation in diamictites along the Vaza Barris fault zone. The Jacaré fault is the most prominent of several NW-SE to WNW-ESE trending lineaments traceable from aerial photographs and topographic maps inside and outside 
the southern part of the area (Fig. 3). Lagarto-Palmares sandstones and metasiltites are intensely fractured, silicified and indurated in different places along the Jacare fault trace. Despite of the lack of kinematic indicators, this fault is interpreted as a normal fault, as it roughly separates $600 \mathrm{~m}$ high hills to the south from $400 \mathrm{~m}$ high hills to the north of its trace. The age of this faulting is uncertain relative to the other regional faults (see further discussion ahead).

$D_{2}$ inter-S $S_{2}$ foliation slip and strain analysis Basement-derived clasts, porphyroclasts and competent minerals are brittlely-ductilely deformed in diamictites, pebbly phyllites, gneiss, and mylonites, either inside or outside the fault zones, suggesting a certain similarity in regional conditions of strain and metamorphism. As well as in the. mylonites, the resistant grains in diamictites and pebbly phyllites are flattened, fractured, pulled-apart and rotated within the $\mathrm{S}_{2}$ planes (Fig. 7a-e) and have a pressure shadow tail consisting of very fine grained, dynamically recrystallised quartz and feldspar, with fibrous overgrowth of very fine sericite, chlorite and minor biotite in the tails and intraclasts voids.

This deformational pattern is observed in quartzites and metacarbonates too, indicating that $\mathrm{D}_{2}$ shortening was coupled with a component of inter-foliation shearing along the WNW-ESE structural grain of the southern part of the Sergipano Belt, thus recording a top to the south movement combined with an E-W sinistral strike-slip along the steep dipping $\mathrm{S}_{2}$ foliation and probably other sub-parallel surfaces.

An extensive study of hundreds of deformed clasts and respective tails in subhorizontal and subvertical surfaces nearly parallel to the $\mathrm{XZ}, \mathrm{XY}$ and $\mathrm{YZ}$ planes of the finite strain ellipsoid in Palestina Formation outcrops (some examples are in Fig. 7) has shown that the ellipsoids have a prolate geometry with $\mathrm{X}$-parallel axis parallel to $\mathrm{B}_{2}$ and $\mathrm{L}_{1-2}$ and generally much longer than the Y-parallel axis (D'el-Rey Silva 1992). This is particularly observed in areas protected from $\mathrm{D}_{2}$ deformation - such as in the west domain and in the core of large $F_{2}$ folds of the regional domain - but, in highly compressed areas the $\mathrm{X}$ : Y ratio is much smaller. This situation suggests a constrictional orogen-parallel strain superimposed by a component of flattening during $\mathrm{D}_{2}$. However, as part of the finite strain is certainly due to $\mathrm{D}_{1}$ deformation, not all the elongation can be taken as evidence of $\mathrm{D}_{2}$-related stretching.

The data have led to the conclusion that $\mathrm{D}_{2}$ strain has been taken up by folding and thrusting, with development of the $S_{2}$ pressure solution foliation, coupled with the ductile elongation and flattening followed by brittle fracturing and rotation of the clasts. A superimposition of $=65 \%$ of shortening of the $\mathrm{S}_{2}$ foliation around the clasts, computed according to the method in Borradaile (1981), highlights the importance of $\mathrm{D}_{2}$ flattening in the area.

Syn- $\mathrm{D}_{2}$ veins and shear bands Quartz and calcite veins commonly cross-cut the $\mathrm{S}_{2}$ foliation in diamictites, in highly foliated metasandstones, phyllites and metacarbonates. As observed in thin sections, these veins are dissolved and shortened by the $S_{2}$ pressure solution and by micro-scale $F_{2}$ folds, or are even displaced along extensional shear bands, rotated and brought sub-parallel to $\mathrm{S}_{2}$. Such features indicate a $\mathrm{D}_{2}$ progressive deformation and are probably due to the orogen-parallel extension following the strain hardening of a highly anisotropic sequence (Platt \& Vissers 1980), probably recording the final stages of ductile deformation before it enters the field of brittle fracturing (Passchier 1984).
The $\mathbf{D}_{\mathbf{3}}$ Deformation is a non-penetrative event indicated by $10 \mathrm{~cm}$ - to $10 \mathrm{~m}$-scale, NE-SW trending, open to tight and generally upright, kink-style $\mathbf{F}_{\mathbf{3}}$ folds and $1 \mathrm{~mm}-10 \mathrm{~cm}$ size crenulations and kink bands affecting the $\mathrm{S}_{2}$ foliation and the older planar elements. The mesoscopic $\mathrm{F}_{3}$ folds are normally associated with a spaced cleavage axial planar foliation (83). The average fold axial plane and the $\mathrm{S}_{3}$ foliation both trend NE-SW and generally dip at moderate to high angles $\left(60^{\circ}-90^{\circ}\right)$ to the NW or to the SE, in all the structural domains. Even where the $F_{3}$ folds are absent, $S_{3}$ is marked by a set of closely spaced, steep dipping to subvertical partition planes. These planes may be the loci of pressure solution seams and may also host subvertical and undeformed quartz or carbonate veins. $\mathbf{L}_{3}$ linear features are the $F_{3}$ fold axis $\left(B_{3}\right)$ and the intersection lineation $\left(\mathrm{L}_{3-2.1}\right)$ which plunges gently to subvertically into a fan of directions between NNW to ENE.

The $\mathrm{F}_{3}$ folds and kinks are better developed in highly anisotropic and subvertical rocks, probably because where $S_{2}$, $\mathrm{S}_{0}\left(\right.$ or $\mathrm{S}_{\mathrm{n}}$ ) and $\mathrm{S}_{1}$ are made parallel after $\mathrm{F}_{1}$ and $\mathrm{F}_{2}$ folding, the contrasting competence of layers provided many slippery surfaces parallel to the regional anisotropy. In such areas, the transverse $\mathrm{F}_{3}$ folds deform the co-axial interference pattern developed by the $F_{1}$ and $F_{2}$ folds, whereas trains of tighter FS folds may occur locally, associated along with strike-slip faults. Best example is seen in the southern part of the Simao Dias dome, in an outcrop of Olhos D'água metacarbonates (locality z, Fig. 3; details in D'el-Rey Silva 1992).

Late stage shearing In some localities of the regional domain, the sub-vertical $S_{2}$ and $S_{3}$ foliations are affected by NNE dipping, discrete brittle fault planes or local brittleductile shear zones, with a listric geometry, and accompanied by sets of en-echelon sigmoidal tension fractures, rotated foliation and quartz veins, all indicative of a top to SSW relative movement late in the evolution of the area.

The Structural domains Sediments in the cratonic domain are barely deformed, but in a locality about $50 \mathrm{~km}$ to the south of the study area, far inside the cratonic domain, the Lagarto-Palmares Formation is affected by a layer-parallel foliation $\left(\mathrm{S}_{1}\right)$ along discrete, $\leq 1 \mathrm{~m}$ thick layers of siltite/ argillite intercalated in sandstones. Approaching the trace of the Itaporanga fault from the S, the Lagarto-Palmares sediments are affected by broad, NW to WNW trending folds, and show a gradual increase in $\mathrm{D}_{2}$ deformation, as $\mathrm{S}_{2}$ passes from micro-crenulation cleavage imprinted in intercalated mudstones, into well defined spaced planes in the Jacare metasiltites and into a mineral foliation in tightly folded Frei Paulo phyllites.

The regional and Simão Dias domains display generally very tight to isoclinal $F_{2}$ folds, with axial planes generally dipping $\geq 60^{\circ}$ to NNE, recording a more intense N-S shortening and more penetrative $F_{3}$ structures than elsewhere. The Itabaiana domain displays important differences in the structural styles and deformational patterns between the gneiss and the Itabaiana quartzites, on each part of the Itabaiana dome. The $F_{2}$ folds tend to be opener than in the regional and Simao Dias domains, and the $\mathrm{S}_{\mathrm{n}} / / \mathrm{S}_{1}$ surfaces are also affected by gentle to open, $100-1000 \mathrm{~m}$-scale $\mathrm{F}_{3}$ folds, resulting in the scattered plot of $\mathrm{S}_{\mathrm{n}} / / \mathrm{S}_{1}$, concentrated near the centre of the diagram (Figs. 5a-b), and also the relative dispersion of $\mathrm{L}_{2} / \mathrm{B}_{2}$ between $270^{\circ}-320^{\circ}$ and $090^{\circ}-140^{\circ}$ (Fig. $5 \mathrm{c}$ ). The east and west domains are characterised by opener $F_{2}$ folds affecting a generally flat-lying, penetrative $S_{1}$ foliation and by the 


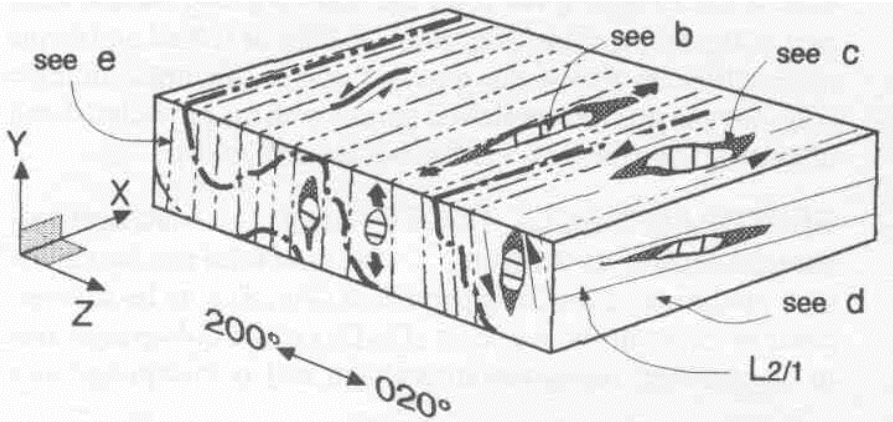

a
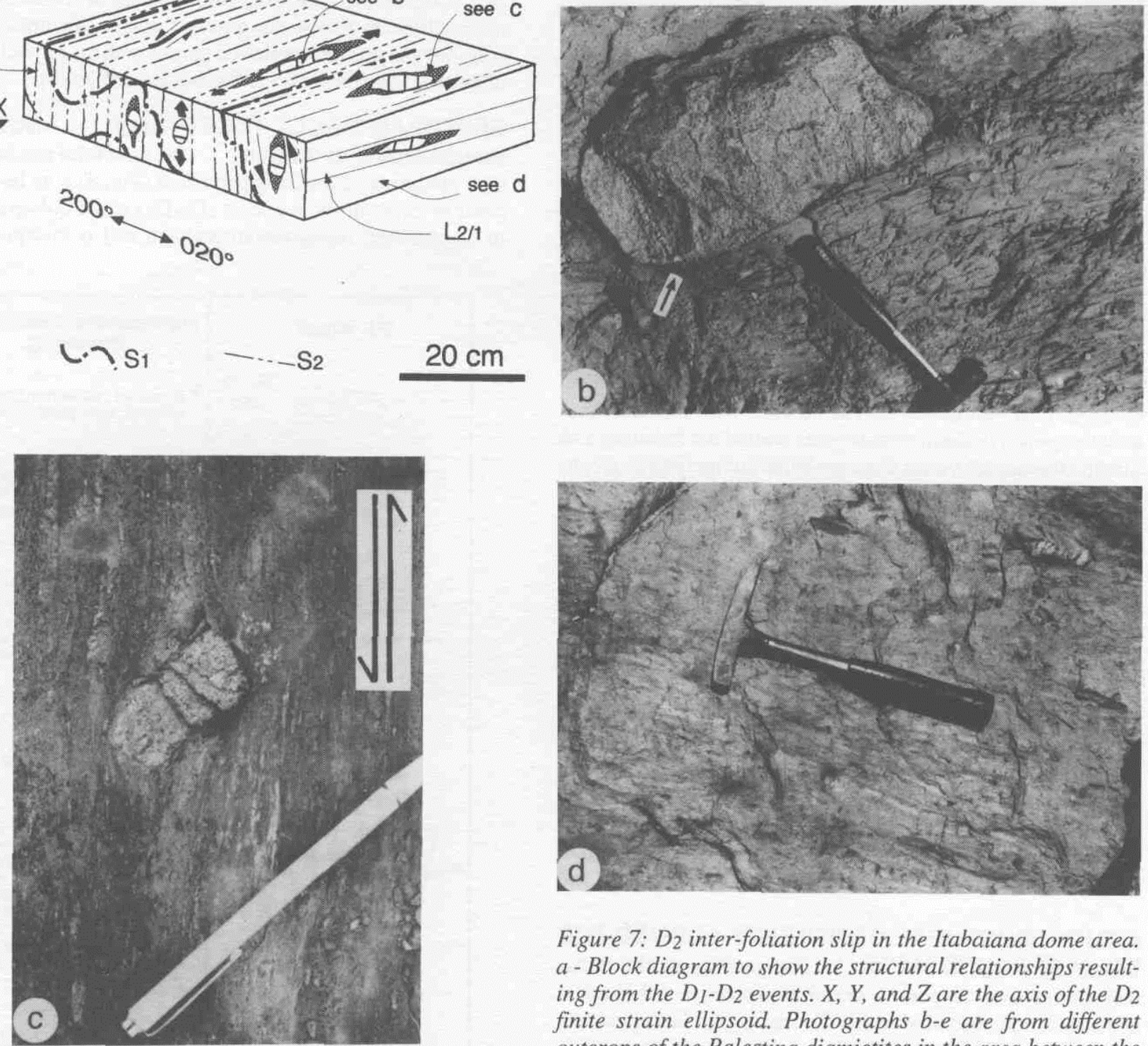

Figure 7: $D_{2}$ inter-foliation slip in the Itabaiana dome area. $a$-Block diagram to show the structural relationships resulting from the $D_{1}-D_{2}$ events. $X, Y$, and $Z$ are the axis of the $D_{2}$ finite strain ellipsoid. Photographs b-e are from different outcrops of the Palestina diamictites in the area between the Escarpa and Pelada faults. $b$-Boulder of basement granitoid fractured and pulled-apart implying $12 \%$ of extension along the $X$ direction (see fibrous quartz healed fractures in the boulder parallel to the $30 \mathrm{~cm}$-long hammer). The sericite-chlorite matrix is also affected by the fractures (arrow). $c$ Transverse fractures and asymmetric pressure shadow tails in a clast of basement granitoid, indicating a WNW-ESE subhorizontal sinistral slip within the $S_{2}$ foliation planes. The white pen is $12 \mathrm{~cm}$-long. $d$ - Gentle plunging stretching lineation defined by fractured and elongated clasts contained in the subvertical $S_{2}$ planes. e-Clasts with fractures and asymmetric tails indicative of a top to the south (left) slip within the subvertical $S_{2}$ foliation (arrows).

Figura 7: Cisalhamento intrafolial durante $\mathrm{D}_{2}$. a - Bloco diagrama mostrando relações estruturais resultantes dos eventos $D_{1}-D_{2} . X, Y$, and $Z$ são eixos do elipsóide de deformação finita $D_{2}$. Fotos b-e são de diferentes afloramentos de diamictitos Palestina na área entre as falhas Escarpa e Pelada. b - Clasto de ortognaisse com fraturas preenchidas por quartzo fibroso. indicando $12 \%$

de extensão ao longo da direção A. A matnz clorítica e também afetada pelas fraturas (seta). Comprimento do martelo $=30 \mathrm{~cm}$. $\mathrm{c}$ - Fraturas de extensao e sombras de pressao assimetricas em clasto de ortognaisse, indicando cisalhamento intrafolial sinistral ao longo de $S_{2}$. Comprimento da caneta $=12 \mathrm{~cm}$. $d-$ Lineação de estiramento definida por clastos estirados na superfftie sub-vertical de $\mathrm{S}_{2}$. e - Clastos com fraturas extensionais e sombras de pressao compatíveis com cisalhamento intrafolial subvertical, topo para sul (esquerda da foto), como indicado pelas setas. 
SSE-NNW trend of $\mathrm{S}_{2}$ and $\mathrm{L}_{2}$ relative to the other domains. In these domains, the bulk of the $=700 \mathrm{~m}$-thick column of the Itabaiana quartzites is almost undeformed, being affected only by subvertical shear zones (eastern side of the Itabaiana dome) and broad-open $\mathrm{F}_{2}$ folds (western side), strongly suggesting that the quartzites acted as a barrier to the deformation (D'elRey Silva 1992, 1995).

Mi and M2 metamorphism The mineralogical assemblages of sericite, chlorite, and biotite associated with the $S_{1}$ and $S_{2}$ foliations and found in fibrous overgrowth around deformed resistant grains suggest similar greenschist facies metamorphism affecting basement and metasediments during $\mathrm{D}_{1}$ and $\mathrm{D}_{2}$, around the Itabaiana and Simap Dias domes. Nevertheless, thin section of Ribeiropolis phyllites have shown interleaved flakes of muscovite and biotite in a single crystal, biotite being partially or totally replaced by chlorite, suggesting that $\mathrm{M}_{1}$ conditions were stronger than the $\mathrm{M}_{2}$ ones. Other specific studies (Jardim de Sa et al. 1981) indicate that metamorphism in the metasediments around the Itabaiana and Simao Dias domes varies from prehnite-pumpelyite to greenschist facies, probably recording temperatures of $300^{\circ} \mathrm{C}$ to $450^{\circ} \mathrm{C}$ and pressures of $1-3 \mathrm{kbar}$. However, the presence of hornblende-epidote paragenesis in the basement of the area may indicate that temperature reached $450^{\circ}-550^{\circ} \mathrm{C}$ (cf. Essene 1989). Metamorphism increases gradually from absent to very low grade conditions, in the cratonic domain, up to greenschist facies northwards, with increasing grain size of phyllitic rocks and increasing amount of syn- and post- $\mathrm{D}_{1}$ quartz veins close to the Sao Miguel do Aleixo fault. Crossing this fault in the central part of the area (Fig. 3) metamorphism passes abruptly to amphibolite facies of intermediate pressures (Santos et al. 1988; Davison \& Santos 1989), but this passage is smoother everywhere else between the southern and northern parts of the Sergipano Belt (Jardim de Sa et al. 1986; Campos Neto \& Brito Neves 1987; D'el-Rey Silva 1992).

LITHOSTRUCTURAL CONTINUITY ACROSS THE DOMAIN BOUNDARIES The geology of the Itabaiana-Carira area supports a craton-miogeocline lithological and structural continuity across the Itaporanga fault (see previous sections) and across the miogeocline-eugeocline boundary.

For the mio-eugeocline continuity the lithological evidence is provided by sheared Itabaiana quartzites and thin slices of phyllonitic gneiss in the hangingwall of the Dores thrust fault. The outcrops of Itabaiana quartzites in the northern part of the area form continuous ranges (Fig. 3) and are probably associated in the field with other outcrops of basement gneiss (M.A. Silva Filho, pers. commun. 1994, based on ongoing regional studies by CPRM). Additional evidence are the similarities between Macurure Group lithologies with the Miaba and Simao Dias groups, and the continuity of the aeromagnetic pattern of the Itabaiana dome gneiss to NNE, across the Dores fault (D'el-Rey Silva 1992, 1995). The structural evidence is provided by the extreme similarity of structural styles across the São Miguel do Aleixo and Dores faults (cf. cross sections in Campos Neto \& Brito Neves 1987, Santos et al. 1988), with support in geophysical indications of the depth of the crystalline basement in the hangingwall of the São Miguel do Aleixo fault (cf. integrated geophysical sections by Motta 1990, in D'el-Rey Silva 1992).
Actually, if the Macurure Group consists of Miaba- and Simao Dias Group-equivalent metasediments, the continuation of the $F_{1}$ structures from the southern into the northern part of the belt would easily stack $\geq 10 \mathrm{~km}$ of folded and thrust metasediments above the granites of the Macurure domain (Fig. 4a) and this interpretation agrees with the predicted depth of granite intrusion (cf. Giuliani \& Santos 1988).

\section{SERGIPANO BELT TECTONICS Structural-} metamorphic evolution The structural and metamorphic evolution of the Sergipano Belt (Fig. 8) may be summarised in terms of three events $\left(D_{1}-D_{3}\right)$ under sub-greenschist to amphibolite facies metamorphism and is interpreted as a

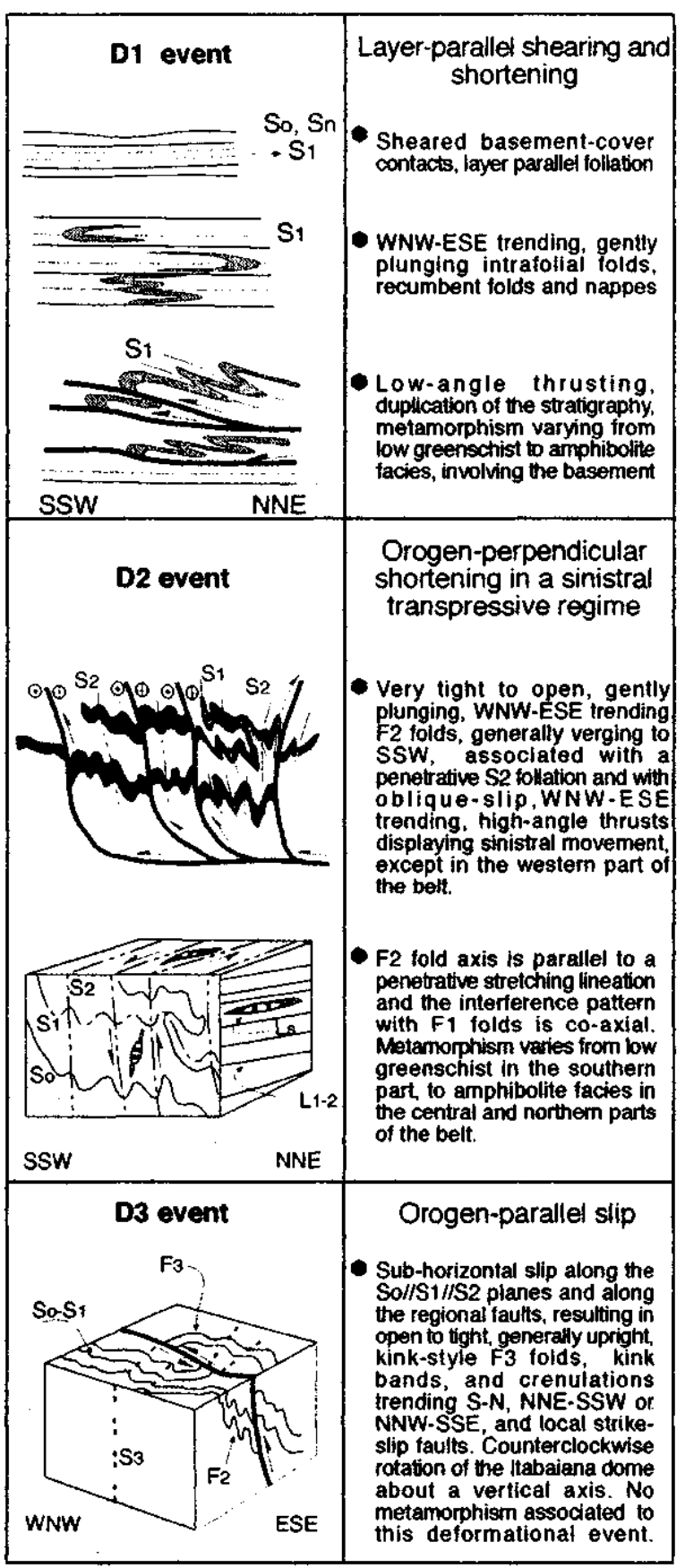

Figure 8: Summary structural and metamorphic evolution of the Sergipano Belt.

Figura 8: Sumário da evolução estrutural e metamórfica da Faixa Sergipana. 
monocyclic tectonic regime under ductile to ductile-brittle conditions of progressive deformation. The crystalline basement in the Itabaiana and Simao Dias domes is clearly involved in these events (D'el-Rey Silva 1992) and this is also valid for the other basement domes in Figure 2, according to Campos Neto \& Brito Neves (1987), Jardim de Sá et al. (1986) and Amorim et al. (1993).

$\mathrm{D}_{1}$ deformation is interpreted as a progressive event of layer-parallel shearing and shortening, and $\mathrm{D}_{2}$ deformation records a progressive shortening by nearly upright folding and high-angle faulting with a kinematics of top to the SSW up-dip movement with a component of orogen-parallel strike-slip movement, probably under a sinistral transpressive regime. The regional faults are interpreted as zones .of strain concentration in the $\mathrm{D}_{2}$ progressive shortening and wrenching. About $55 \%$ of $\mathrm{N}-\mathrm{S}$ shortening is implied by $\mathrm{D}_{1}-\mathrm{D}_{2}$ deformation (computations on the Olhos D'agua metacarbonates above the erosion line, Fig. 4a; D'el-Rey Silva 1992). $D_{3}$ is interpreted as a non penetrative and non metamorphic event of shortening and extension transversal to the belt.

A transpressive regime is supported by several features of the Sergipano Belt matching descriptions of other deformed belts where a combination of shortening and wrenching strains has been evoked: e.g. the parallelism of fold axes and stretching lineations, both perpendicular or at high-angle with the direction of tectonic transport (Lagarde and Michard 1986; Ridley 1986; Ellis and Watkinson 1987) and the interfoliation slip along strike and dip of the axial plane foliation of the regional folds (Ghosh 1982).

The local metamorphic break across the São Miguel do Aleixo fault and the local northerly vergence of $D_{2}$ structures in the northeastern part of the belt (Fig. 2) may be explained as part of a late- $\mathrm{D}_{2}$ positive flower structure $\left(\mathrm{D}_{2}\right.$ event in Fig. 8), which is also commonly developed under transpression (e.g. Odonne and Vialon 1983). A transpressive regime accounts for the opening of small late- to post-tectonic intermontane basins by continued belt-parallel extension, such as the Juf Formation graben.

Amorim et al. (1992) and Amorim \& Torres (1994) described an ESE-WNW trending stretching lineation to the north of the Jirau do Ponciano dome and to the north of the Macurure fault, associated with SW-NE trending $F_{2}$ folds and low-angle faults dipping to SSE with top to WNW and NW movement, in areas where several ESE-WNW trending strikeslip faults also occur (nearby localities C, E, F and G, Fig. 2). Although these authors argue for a polycyclic evolution in the northernmost part of the Sergipano Belt, such set of structures may be alternatively interpreted as a template of frontal and lateral ramps affecting the high-grade metasediments and reworking the Pernambuco-Alagoas Massif, kinematically compatible with the Neoproterozoic deformational evolution of the belt, as described here.

Destro et al. (1993) proposed that the entire northern part of the Sergipano Belt should be considered a completely different belt, just on the basis of structural data collected mostly from deformed quartz veins in an area to the south of the Jirau do Ponciano dome, but away from the border of the Vaza Barris and Macururé domains. Their arguments are highly debatable because among the tectonic requirements to demonstrate that two belts were brought together, the São Miguel do Aleixo fault system has no affinities with any kind of terrane boundary. Moreover, as is being increasingly recognised, the internal part of orogens (Wu 1993 and others therein) and accretionary wedges (Kimura \& Hori 1993) commonly display more deformational events than the external zones. Therefore, caution is a must when interpreting tectonic evolution based on simple structural data. Additionally, their folded quartz veins are kinematically compatible with a first stage of the progressive $D_{1}$ event in the Sergipano Belt.

Evolution of the basement domes The evolution of the basement domes in the Itabaiana-Carira area has been treated in detail (D'el-Rey Silva 1992,1995). In summary, the Itabaiana dome likely started to evolve as a syn-depositional rollover anticline-syncline pair developed above a ramp-flat listric extensional detachment, in order to explain the huge thickness of the Itabaiana Formation and the lithofacies of the Ribeiropolis Formation around the dome. The crown of Jacoca carbonates records the progressive uplift of the dome whereas the Vaza Barris trough may have been a ramp syncline or a crestal collapse graben developed at this time. Under compression, this precursor dome evolved into a progressively overturned anticline by superimposed $D_{1}-D_{2}$ shortening. Because of the barrier of quartzites, the basement below was hotter and more ductilely deformed, and the sediments above were detached and tightly folded.

The Macambira phyllonites and the extensional shear bands affecting the $\mathrm{S} / \mathrm{C}$ foliation in the western part of the dome (Fig. 3) probably play the role of an extensional collapse of the hinge of the major fold (top down to WNW, along the fold axis), made easier by the existence of a gliding plane along the contacts of the Itabaiana thick quartzites with the basement (below) and the Ribeiropolis phyllites (above). Late in the evolution of the area, the dome also underwent a $25^{\circ}$ counter-clockwise rotation.

The Simao Dias dome probably evolved as a series of extensional basement slices, simultaneously with the sedimentary stage in the evolution of the Itabaiana dome and the Vaza Barris trough. These slices were subsequently folded and uplifted during the positive inversion of the listric faults. Other basement domes in the belt (Fig. 2) still demand a detailed study.

Progressive deformation and late- to post-Di extension The Capitao farm outcrop (Fig. 9) is a $\geq 400 \mathrm{~m}$ long and about $60 \mathrm{~m}$ high, SW-NE trending wall digged up by the main river in the area, in the western side of the Itabaiana dome (locality w, Fig. 3). It displays crossbedded Itabaiana quartzites (at the bottom, in the southern part), overlain by $5 \mathrm{~m}$ thick Ribeiropolis coarsening-up metaconglomerates that underlain Jacoca metacarbonates (the main features of part of the outcrop are in Fig. 9a). The lowest 8 meters of the wall were mapped at a 1:100 scale (D'el-Rey Silva 1992; part of it is in Fig. 9b).

The dominant structures are $F_{1}$ folds and sub-horizontal thrusts (Fig. 9a), and a strong $S_{1}$ foliation which is layerparallel in dolomitic layers and refracts to a low angle in intercalated metapelite/metasiltite layers of the Jacoca Formation. Several small-scale structures indicate that $\mathrm{D}_{1}$ deformation took place progressively by top to SSW layer parallel shearing, developing and folding the $\mathrm{S}_{1}$ foliation to generate a less penetrative $S_{1 a}$ foliation (details 1-3), emplacement, rotation, and subsequent folding of $S_{1}$-parallel dolomite veins (details 4-5, sketch 6). 
In the lowest part of the outcrop (see left end of Fig. 9b), the basal section of the metacarbonates and the metaconglomerates are ductilely-brittlely extended and are cut by a sequence of NNE dipping, high-angle normal faults that bend and flatten into a listric geometry (see right end). They most likely merge in a top-down to the $\mathrm{N}$ basal detachment that must exist somewhere below in the quartzites. This is because the metaconglomerates are highly sheared along the basal and upper contacts, just in the vicinities of the brittle-ductile extensional features (Fig. 9b). Well developed S-C foliations clearly indicate a top down to NNE, and top to SSW movements, respectively in these basal and upper contacts. The $2 \mathrm{~m}$-thick basal layer of massive dolomites is disrupted by the normal faults and appears again outside, to the right of Figure $9 \mathrm{~b}$, being separated into Im-sized boudins with $10 \mathrm{~cm}$-scale internal folds and occurring meters away from each other, along the flat-lying contact with the conglomerates.

In the hangingwall of the normal faults, the Si foliated Jacoca Formation is affected by mesoscopic, asymmetric, isoclinal folds with NNE dipping curved axial planes that mimic the fault planes (Fig. 9a-b show only an example). These folds develop a penetrative pressure solution axial planar foliation, and the overturned limbs are associated with reverse faults parallel to the normal faults (Fig. 9b), whereas the normal limbs, which are very close to the normal fault planes, are extremely thinned and affected by conjugate extensional shear fractures (detail 7). The data indicate that these folds, and the reverse faults developed in their overturned limbs, are accommodation ductile-brittle structures related to the deformation normally affecting the hangingwall of listric extensional systems (cf. Wernicke and Burchfiel 1982, Gibbs 1984).

Because the normal faults affect Si-foliated metacarbonates, it may be concluded that the top-down to the N sub-horizontal extensional detachment to which these faults are associated records late- to post- $\mathrm{D}_{1}$ extensional deformation in the area, perhaps contemporaneous with the $\mathrm{D}_{2}$ event in the study area, simply because no $F_{2}$ folds have been seen affected by normal faults in the area, nor have they been described in the literature of the belt (D'el-Rey Silva 1992).

Implications of the upper siliciclastic megasequence The geology of the Itabaiana-Carira area does not support thrust belt-foreland basin models to explain the upper section of the cratonic sediments in the southern part of the belt [the massive sandstones of the Palmares Formation], as thoroughly accepted in the literature. Instead, the origin of these sandstones and the whole of the Simao Dias Group, plus the Palestina diamictites (in fact the origin of the upper siliciclastic megasequence) is better assigned to a progressively faster uplift of the centre of the Sao Francisco Craton, resulting in the peripheral delamination of the craton margins and forming a rim of precursor basins (D'el-Rey Silva 1992, 1994a).

The erosion of such a dynamic source, far to the south, would provide an increasing supply of coarsening-upwards sands (The Lagarto-Palmares Formation), possibly transported by a braid delta system (sensu McPherson et al. 1987) and reworked by waves, after deposition on top of the Acaua carbonates into a shallow water platform. The Jacare metasiltites and the Frei Paulo phyllites record a more distal position of the Simao Dias Group within the basin. The Palestina diamictites most likely record the peak of syn-depo- sitional extensional tectonism associated with craton uplift and continental break-up leading to the opening of the Caninde Sea.

DISCUSSIONS AND CONCLUSIONS The Sergipano Belt is a single and continuous tectonic entity with many features typical of other Proterozoic belts, particularly those in the Pan-African/Brasiliano orogeny. The continuity within the sedimentary-volcanic record has been also demonstrated in other parts of the megaorogen, such as in the North Equatorial (Oubanguides) Belt of Africa (Nzenti et al. 1988), in the Rio Preto Belt (Egydio da Silva et al. 1989), and is not disregarded in the Riacho do Pontal Belt (e.g. Gomes 1990, Jardim de Sá et al. 1992).

The Sergipano Belt may be interpreted in terms of a classical collisional orogen resulting from the closure of the Caninde sea, the life of which may explain the Estancia-Vaza Barris-Macurure domains as a craton-miogeocline-eugeocline single wedge developed on an asymmetric basin that evolved into an ocean, and may explain the Marancó and Pogo Redondo domains, for example as a magmatic arc (Marancó) developed by subduction of the oceanic crust underneath a continental fragment (Poço Redondo). Alternatively, the Marancó domain may be the record of felsic-intermediary volcanism within the precursor basin undergoing large-scale syn-depositional extension, and the Poço Redondo domain is a reworked and uplifted slice of the northern margin of the São Francisco Craton. Although the second alternative fits better with isotopic data in Van Schmus et al (1993), both interpretations argue for more detailed studies on the geochemistry of the Marancó domain and about the characteristics and provenance of the siliciclastic sedimentation already described within the Marancó domain by Santos et al. (1988). The island arc-like geochemical signature of most of the Caninde domain, coupled with a northward polarity in the alkalinity of the granites in the Macurure, Marancó and Caninde domains (da Silva Filho et al. 1992), both support the interpretation of an episode of B-subduction to the north, perhaps with a back-arc setting.

Overall, a suture line has been interpreted along the trace of the Macurure fault (Fig. 2; D'el-Rey Silva 1992) which continues into the Riacho do Pontal Belt (Jardim de Sá et al. 1992), according to an aeromagnetic geophysical anomaly along the northern margin of the São Francisco Craton (Torres et al. 1994). This suture drives attention on the role of the Pernambuco-Alagoas Massif in the evolution of the Sergipano Belt and the Borborema Province.

The first systematic descriptions pointed to the massif as a wide variety of Archean to Paleoproterozoic gneiss-granitemigmatitic rocks, pierced by Neoproterozoic granites and syenites (Brito Neves et al. 1982). More recently Silva Filho (1995) suggests that the massif may be in part a plutonic arc built around $980 \mathrm{Ma}$ ago. New Sm-Nd and U-Pb isotopic data from samples of the southern part of the massif have driven Van Schmus et al. $(1993,1995)$ towards preliminary interpretations that parts of the massifs gneiss and Brasiliano-cycle granites derive from 1.3-1.7 Ga protoliths, and that the massif itself is a fragment of a continental crust increased by juvenile material during a major, $1.0+/-0.1$ Ga old episode of continental extension that affected a much wider block, a remnant of which is possibly the Sao Francisco Craton.

Although these authors question the existence of any Neoproterozoic island arc in the Borborema Province, they accept 


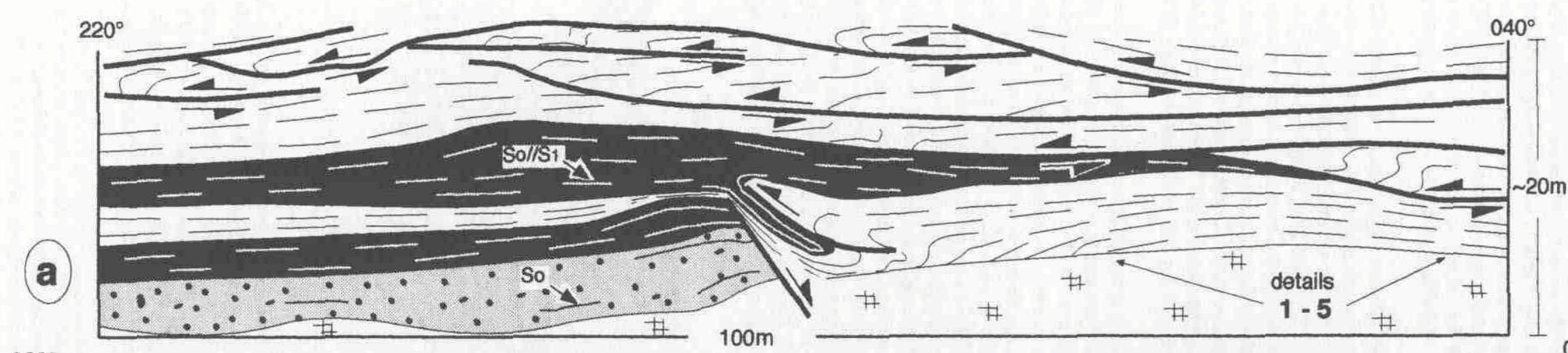

$220^{\circ}$

$100 \mathrm{~m}$

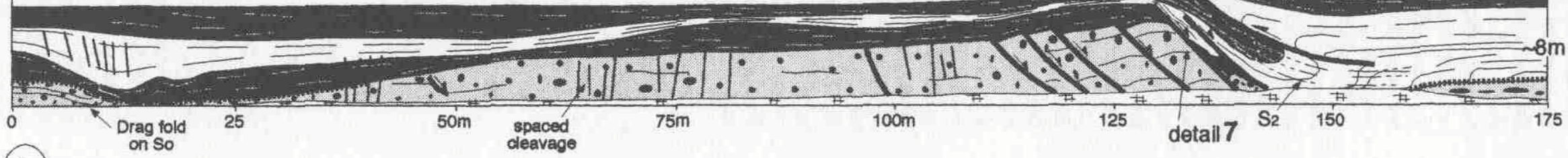

(b) $\#+$ Recent

-. Conglomerates

"unnuan, sheared

Massive
dolomites

$\sum \begin{aligned} & \text { Interlayered dolomites, } \\ & \text { metapelites, metasifitites }\end{aligned}$
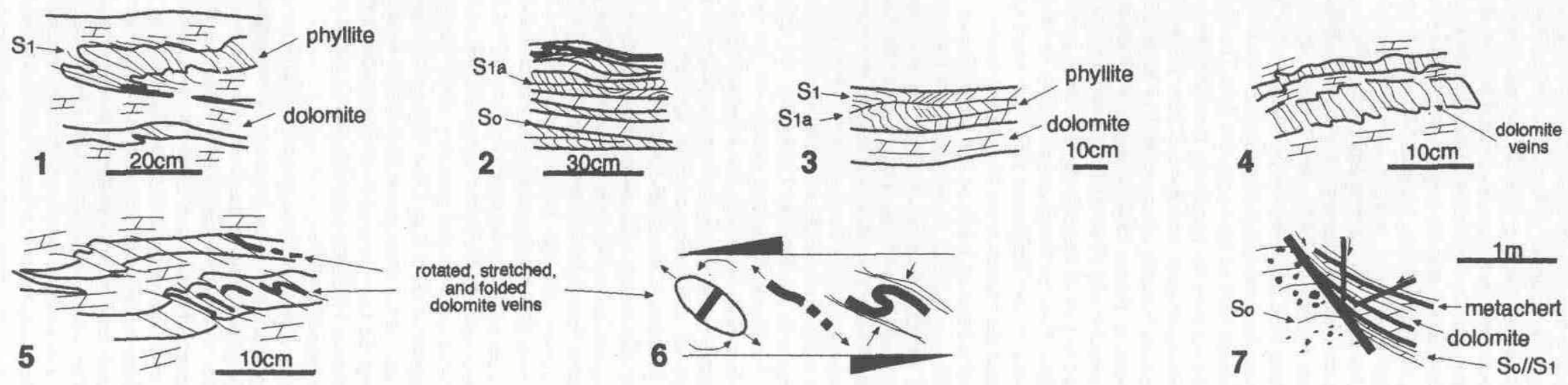

Figure 9: Structural relationships in the Capitão Farm outcrop ( $a-b)$. Skectches 1-5 and 7 are line drawing on photographs of the outcrop, and 6 is an interpretation. See text. Relates estruturais no afloramento da Fazenda Capitão (a - b). Diagramas $1-5$ e 7 são desenhos sobre fotografias do afloramento, e 6 e interpretação. Detalhes no texto. 
a drift (how far?) of the massif from the São Francisco Craton. This interpretation matches the initial stage of opening of the precursor Sergipano basin (D'el-Rey Silva 1992,1994b), but their data neither rule out the Canindé sea nor constrain its width. Moreover, even being an extensional terrane, the Borborema Province may not be derived from the Sao Francisco Craton, and the Caninde domain may be entirely allochtonous.

Therefore, the Pernambuco-Alagoas Massif may play the role of another continental margin, or a microcontinent whichever is the age of its splitting and drift - colliding with the São Francisco Craton and being reworked in the Brasiliano orogeny, about $650 \mathrm{Ma}$ ago (Fig. 10). In both situations, a plutonic arc may have been built on the massif and a $980 \mathrm{Ma}$ old arc, if the age is correct, does not disagree, with the $1.0+/-$ 0.1 age of sedimentation in the Sergipano Belt. The available data do not rule out even the possibility that the amphibolites, metachert, metacarbonates and banded iron formations of layered sequences recently characterised in localities A-G (Fig. 2; Amorim \& Torres 1994) compare with deep-water assemblages found in other Pan-African/Brasiliano fold belts, and interpreted as part of accretionary prisms (e.g. Kukla \& Stanistreet 1991, Pedrosa Scares et al. 1994). In this case, these sequences in the Sergipano Belt may even contain tectonic slices of the oceanic crust (the amphibolites).

The lack of a foreland basin in the southern part of the Sergipano Belt may be due to erosion, or it has not been developed at all (D'el-Rey Silva 1992). In that case, the progressive crustal loading in the inner parts of the belt may have been accompanied by downwarping of the attenuated continental crust of the Sao Francisco Craton (Fig. 10), so that no significant relief emerged above sea level. A similar argument was proposed by Tankard (1986) for the Paleozoic evolution of the North American margin on the basis of geophysical data. Fold belts with low topographic elevation and little denudation can also be generated at plate boundaries where the rate of subduction exceeds the rate of overall convergence (Royden \& Burchfiel 1989).

Any degree of obliquity or a continued convergence would lead to a transpressive regime (e.g. Shackleton 1986), giving rise to the dextral Pernambuco Shear Zone (Fig. 10) in mature stages of collision. As the Pernambuco-Alagoas Massif moved to the west along the bending of the Pernambuco Shear Zone (Fig. 2), the maximum differential stress (91-3 3) may have rotated to a more southerly direction, and this, combined with the probable tooth-shaped geometry of the western part of the precursor basin (D'el-Rey Silva 1992), may explain the dextral strike-slip along the regional faults of the western part of the belt (Fig. 2). Late- to post-tectonic granites in the belt (Giuliani \& Santos 1988) are probably due to partial melting of an overthickened crust.

The abundant indicators for a top up to the SSW movement and the strati graphic inversions demonstrate the contractional nature of the regional faults in the Sergipano Belt, but do not allow to decide whether over or underthrusting was the main process for crustal thickening. If the craton was pulled down to the north by a sinking oceanic slab (Fig. 10), then underthrusting should be the dominant process, because the lower continental crust carries down the more buoyant upper crust and sedimentary cover, but all going into subduction. Recent geophysical data confirm earlier predictions that compressional mountain belts result essentially from the passive sinking of the lower continental crust attached to the underlying lithospheric mantle, so the upper continental crust is then shortened by internal nappes and external thrusts (Epard \& Escher 1996, in press, and references therein). The nappes in the cratonic area in the western part of the belt (Fig. 10; Jardim de Sá et al. 1986) may even be explained by basement-cored diapiric extrusion of less viscous material below the upper cover, as demonstrated experimentally by Talbot (1974). Such a process should be added to the whole evolution of the basement domes in the belt, because all of its ingredients are available.

The model (Fig. 10) also suggests that the border of the Sao Francisco Craton underwent post- $\mathrm{D}_{1}$, possibly syn- to late- $\mathrm{D}_{2}$ extension in response to tectonic loading (similarly as in Bradley \& Kidd 1991) and that compressive and extensive stresses may have operated simultaneously along some of the regional contractional faults. These assumptions account for the post- $\mathrm{D}_{1}$ extension in the Capitao farm outcrop, and provides a feasible explanation for the Jacare extensional fault in the cratonic area, and for the carbonate breccia along the Itaporanga fault.

A comprehensive research is required in a key area comprising part of the Pernambuco-Alagoas Massif and adjacent lithotectonic domains in the belt, based on sedimentary, paleomagnetic, structural-metamorphic analysis coupled with determination of absolute and relative ages of deformational events, P-T-t history, and more detailed geochemistry and isotopic studies. These will provide more definitive answers about poly or monocyclic evolution, and about the evolution of the massif and its role in the tectonics of the area. Detailed studies are also required on the deformation of the sediments in the Estancia domain, far into the Craton, to understand the role of the layer-parallel foliation existing there. Similar ongoing studies in the cratonic domain of the Brasilia Belt (D'el-Rey Silva \& Pereira 1995) have pointed out into alternative models, other than the classical foreland fold-and-

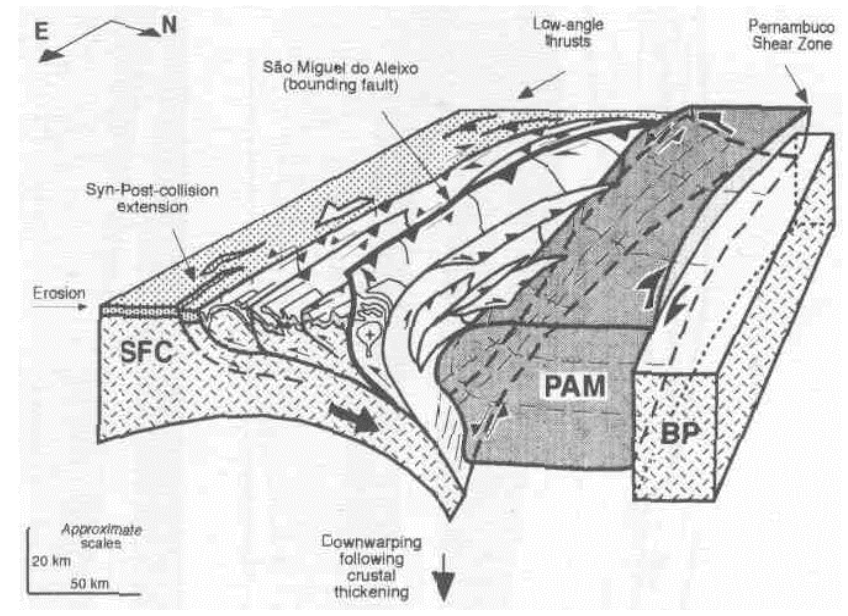

Figure 10: Cartoon to illustrate a model for the tectonic evolution of the Sergipano Belt (D'el-Rey Silva 1992), based on the oblique collision of the São Francisco Craton (SFC) and the southern part of the Borborema Province (BP), resulting in the displacement of the Pernambuco-Alagoas Massif (PAM) to the west, along the dextral Pernambuco Shear Zone. See text.

Figura 10: Diagrama ilustrando modelo de evolufao tectônica da Faixa Sergipana (D'el-Rey Silva 1992), a partir da colisao obliqua do Cráton de São Francisco (SFC) com a parte sul da Província Borborema (BP), resultando no deslocamento do Maciço Pernambuco-Alagoas (PAM) para W e para cima, ao longo do cisalhamento Pernambuco. Detalhes no texto. 
thrust belt, in order to explain simultaneous extensional and contractional structures found more than $50 \mathrm{~km}$ inside the São Francisco Craton.

The Sergipano Belt is a single tectonic unit comprising three (meta)sedimentary-volcanic domains deposited around basement gneiss domes, two igneous domains and a migmatitic domain, all separated by regional faults with composite up-dip and strike-slip movements. These domains may be all explained by the time-life of an ocean basin (the Canindé sea), and by a typical collision between the southern part of the Borborema Province and the Sao Francisco Craton. Because the Sergipano Belt contains unique features that provide data for the lack of foreland basin sediments in its southern part, this must be considered as a strong possibility at least for other belts around the Sao Francisco Craton.

Acknowledgments CNPq-Brazil is thanked for Grants 200.025/88-3, 301.102/92, 400.037/93-9 and 520.241/95.9. B.B. Brito Neves (USP, Brazil) is thanked for discussion on the deformation of the cratonic cover of the belt (February 1995). R.A. Fuck (UnB, Brazil) is thanked for reading and criticism on the manuscript.

\section{REFERENCES}

ALLARD, G.0.1969. The Proprid geosyncline, a key tectonic element in the continental drift puzzle of the South Atlantic. In CONG. BRAS. GEOL, 23, Salvador, Anais... Salvador SBG, v.1, p.47-59.

ALLARD, G.O. \& HURST, V.J. 1969. Brazil-Gabon geologic link supports continental drift. Science, 163: 528-532.

ALMEIDA, F.F.M. de, HASUI, Y., BRITO NEVES, B.B. de, FUCK, R.A. 1981. Brazilian Structural Provinces: an introduction. Earth Sci. Rev., Special Issue 17: 1-29, Amsterdam.

AMORIM, J.L., TORRES, H.H.F., SILVA FILHO, M.A. da 1992. Transporte tectônico reliquiar na Faixa Sergipana. In CONG. BRAS. GEOL, 37, Sao Paulo, Bol. de Res. Expandidos...São Paulo SBG, v.l, p.308309

AMORIM, J.L. \& TORRES, H.H.F. 1994.0 limite entre as Faixas Sergipana e Sul-Alagoana. In CONG. BRAS. GEOL, 38, Balnedrio Camboritf, Bol. de Res. Expandidos...Balnezno Camboriu, SBG, v.l, p.250-252.

AMORIM, J.L., TORRES, H.H.F., SILVA FILHO, M.A. da 1993. O Complexo de embasamento da Faixa Sergipana na regiao de Jirau do Ponciano (Al): Estratigrafia, evolufSo tectonometamorfica e potencialidade metalogen\&ica. In SIMP. GEOL. NORDESTE, 15, Natal, Bol. de Resumos...Natal, SBG-NE, p.240-242.

BLAIS, S., JARDIM DE SA, E.F., BEZERRA,F.G.R., NILSON, A.A. 1989. Preliminary data on the Canind6 Complex, Sergipe Belt (northeast Brazil): a Brasiliano island arc?. Terra Abstracts, 1:273.

BEZERRA, F.H.R., NILSON, A.A., BLAIS, S., JARDIM DE SA, E.F. 1990. Contribuição a geologia e geoquimica do complexo Canindd do Sao Francisco e rochas encaixantes (Se-Al). In CONG. BRAS. GEOL, 36, Natal, Bol. de fo.vMm<w...Natal, SBG, p.305.

BRADLEY, D.C. \& KIDD, W.S.F. 1991. Flexural extension of the upper continental crust in collisional foredeeps. Geol. Soc. Am. Bull., 103: 1416-1438.

BRITO NEVES, B.B. de \& CORDANI, U.G. 1973. Problemas geocronologicos do "Geossinclinal Sergipano" e do seu embasamento. In CONG. BRAS. GEOL., 27, Aracaju, Anais...Aracaju, SBG, v.1, p.67-76.

BRITO NEVES, B.B. de, SIAL, A.N., ALBUQUERQUE, J.P.T. 1977. Vergfincia centrifuga residual no sistema de dobramentos sergipano. Rev. Bras. Geoc., 7: 102-114.

BRITO NEVES, B.B., SIAL, A.N., RAND, H.M., MANSO, V.V. 1982. The Pernambuco-Alagoas Massif, Northeastern Brazil. Rev. Bras. Geoc., 12 (1-3): $240-250$

BRITO NEVES, B.B. de, VAN SCHMUS, W.R., BABINSKI, M., SABIN, T., 1993.0 evento de magmatismo de 1,0 Ga nas faixas moveis ao norte do Craton Sao Francisco. SIMP. CRATON S. FRANCISCO, 2, Salvador, Ana/.v...Salvador, SBG-SGM, p.243-245.

BORRADAILE, G.J. 1981. Minimum strain from conglomerates with ductility contrast. J. Struc. Geol., 3: 295-297.

CAMPOS NETO, M. da C. \& BRITO NEVES, B.B. de 1987. Considerações sobre a organização e geometria do Sistema de Dobramentos Sergipano. In SIMP. NAC. EST. TECT6NICOS, 1, Salvador, Boletim de Resumos... Salvador, UFBa, p.90-93.

CHAVES, J.M. 1991. Macicos Coronet João Sá e Gloria. Petrologia de granitóides no dommio Macurure, Faixa Sergipana (NE Brasil). Salvador, 153p (Dissertacao de Mestrado, UFBa).

DALZIEL, I.W.D. 1992. On the Organization of American Plates in the Neoproterozoic and the Breakout of Laurentia. GSA Today, 2 (1): 237-241.

da SILVA, M.R.R. 1993. A zona de cianita na Faixa Sul-Alagoana, sistema de dobramentos Sergipano - NE Brasil. SIMP. GEOL. NORDESTE, 15, Natal, Bol. 13...Natal, SBG, p.134-136. da SILVA FILHO, A.F., GUIMARAES, I. P., da SILVA, M.R.R. 1992 Utilizacao de granitdides na defmi9§o de domfnios tectdnicos, aplicação no lado oriental do sistema de dobramentos Sergipano. In CONG. BRAS. GEOL., 37, São Paulo, Bol. Res. Expandidos...Sao Paulo, SBG, v.1,p.358-359.

DAVISON, I. \& SANTOS, R.A. dos 1989. Tectonic Evolution of the Sergipano Fold Belt, NE Brazil, during the Brasiliano Orogeny. Precambrian Research, 45: 319-342.

D'EL-REY SILVA, L.J.H. 1992. Tectonic evolution of the southern part of the Sergipano Fold Belt, northeastern Brazil. London, 257p (PhD Thesis, Royal Holloway University London).

D'EL-REY SILVA, L.J.H. 1993. Evolugao tectSnica da Faixa Sergipana e implicações para o sistema Brasiliano - Panafricano. In SIMP. CRATON SÃO FRANCISCO, 2, Salvador, Anais...Salvador, SBG/SGM, p.246-248.

D'EL-REY SILVA, L.J.H. 1994a. The Sergipano Fold Belt and Implications for Proterozoic Tectonics. In CONG. BRAS. GEOL., 38, Balneario Camboriú, Bol. Res. Expandidos...Balneario Camboriu, SBG, v.l, p.265-267.

D'EL-REY SILVA, L.J.H. 1994b. The Sergipano Fold Belt, NE Brazil: Current Tectonic Synthesis. In CONG. BRAS. GEOL., 38, Balneario Camboriu, Bol. Res. Expandidos...Balneario Camboriti, SBG, v.l, p.254-256.

D'EL-REY SILVA, L.J.H., 1995. The evolution of basement gneiss domes of the Sergipano fold belt (NE Brazil) and its importance for the analysis of Proterozoic basins. J. S. Am. Earth Sci., 8: 325-340.

D'EL-REY SILVA, L.J.H. \& PEREIRA, C.J. 1995. Deformações brasilianas da Formação TrSs Marias na região de Urucuia, MG: Implicates para a evolução tectdnica da Faixa Brasilia. In SIMP. NAC. EST. TECTONICOS, 5, Gramado, Anais...SBC, p.23-25.

D'EL-REY SILVA, L.J.H. \& MCCLAY, K.R. (1995). Stratigraphy of the southern part of the Sergipano Belt and tectonic implications. Rev. Bras. Geoc., 25(3) (in press).

DESTRO, N., MAGNAVITA, L.P., de ARAGAO, M.A.N.F. 1993. Faixa de dobramentos do Baixo São Francisco: individualizão tectônica do segmento norte da Faixa Sergipana. SIMP. CRATON S. FRANCISCO, 2, Salvador, Anais...Salvador, SBG p.312-314.

EGYDIO da SILVA, M., KARMANN, I., TROMPETTE, R. 1989. Litoestratigrafia do Supergrupo Espinhaço e Grupo Bambui no Noroeste do Estado da Bahia. Rev. Bras. Geoc., 19: 141-152.

ELLIS, M. \& WATKINSON, A.J. 1987. Orogen-Parallel extension and oblique tectonics: the relation between stretching lineations and relative plate motions. Geology, 15:1022-1026.

EPARD, J-L. \& ESCHER, A. 1996 (in press). Transition from basement to cover: a geometric model. J. Struc. Geol., 18(5), in press.

ESSENE, E.J. 1989. The current status of thermobarometry in metamorphic rocks. In DALY, J.S., CLIFF, R.A., YARDLEY, B.W.D. eds. Evolution of Metamorphic Belts, Geol. Soc. London Sp. Pub. 43, p. 1-44.

FUJIMORI, S. 1989. Contribuição estudo de granitóides do sistema de dobramentos Sergipano. Rev. Bras. Geoc., 15(2): 241-247.

GAVA, A., NASCIMENTO, D.A. do, VIDAL, J.L.B., GHIGNONE, J.I., OLIVEIRA, E.P. de, SANTIAGO, P, A.L., TEIXEIRA, W. 1983. Projeto RADAMBRASIL, Geologia. Mapa Geol6gico, Folhas SC.24/25, Aracaju/Recife, escala 1:1,000,000, Rio de Janeiro, Levantamento de Recursos Naturais 30.

GIBBS, A.D. 1984. Structural evolution of extensional basin margins. /. Geol. Soc. London, 141: 609-620.

GHOSH, S.K. 1982. The problem of shearing along axial plane foliation. J. Struc. Geol., 4: 63-67. 
GIULIANI, G. \& SANTOS, R.A. dos 1988. Geoqufmica de alguns granitdides da Faixa de Dobramentos Sergipana. In CONG. BRAS. GEOL., 35, Belém, Anais. ..Betem, SBG, v.3, p. 1037-1052.

GOMES, F.E.M. 1990. Relações litoestratigraTico-estruturais e evolução tect6nica na faixa Riacho do Pontal - Região de Paulistana (Pi). In CONG. BRAS. GEOL., 36, Natal, Anau...Natal, SBG, v.6 p.2843-2857.

GRAY, D.R. 1977. Morphologic classification of crenulation cleavage. $J$ of Geol, 85: 229-235.

HOFFMAN, P.P. 1991. Did the breakout of Laurentia turn Gondwanaland inside-out?. Science, 252: 1409-1412.

HUMPHREY, F.L. \& ALLARD, G.O. 1968. The Proprid geosyncline, a newly recognised tectonic element in the Brazilian shield. In INTERN. GEOL. CONG., 23, Prague, v.4, p. 123-139.

JARDIM de SA, E.F., LEGRAND, J.M., HACKSPACHER, P.C. 1981. Contraste de estilos estruturais e metamorficos na faixa dobrada Sergipana. Rev. Bras. Geoc., 11: 128-137.

JARDIM de SÁ, E.F., MORAES, J.A.C. de, D'EL-REY SILVA, L.J.H. 1986. Tect6nica tangencial na Faixa Sergipana. In CONG. BRAS. GEOL., 34,Goiania,/Anais...Goiania, SBG, v.3, p.1246-1259.

JARDIM de SA, E.F., MACEDO, M.H.F., FUCK, R.A., KAWASHITA, K. 1992 - Terrenes proterozóicos na Provincia Borborema e a margem norte do Craton Sao Francisco. Rev. Bras. Geoc., 22: 472-480.

JARDIM de SÁ, E.F. 1994. A Faixa Seridd (Provincia Borborema, NE do Brasil) e o seu significado geodindmico na cadeia Brasiliana/Pan-Africana. Brasilia, $803 \mathrm{p}$ (Tese de Doutorado No. 3, UnB).

KIMURA, K. \& HORI, R. 1993 -Offscrapping accretion of Jurassic chertclastic complexes in the Mino-Tamba Belt, central Japan. J. Struc. Geol, 15(2): 145-161.

KUKLA, P.A. \& STANISTREET, I.G, 1991. Record of Damaran Khomas Hochland accretionary prism in Central Namibia: Refutation of an "ensialic" origin of a Late Proterozoic fold belt. Geology, 19:473-476.

LAGARDE, J.L. \& MICHARD, L. 1986. Stretching normal to the regional thrust displacement in a thrust-wrench shear zone, Rehamna Massif, Morocco. J. Struc. GeoL, 8: 483-492.

LISTER, G.S. \& SNOKE, A.W. 1984. S-C Mylonites. J. Struc. GeoL, 5/6: 617-638.

MASCARENHAS, J. de F., MISI, A., MOTTA, A.C., SA, J.H. da S. 1984. Provincia Sao Francisco. In ALMEIDA, F.F.M. de \& HASUI, Y. coord. O pre-Cambriano do Brasil. Ed. Edgard Blucher Ltda. p.46-122.

McPHERSON, J.G., SHANMUGAN, G., MOIOLA, R.J. 1987. Fan deltas and braid deltas: varieties of coarse-grained deltas. GeoL Soc. Am. Bull., 99: 331-340.

NZENTI, J.P., BARBEY, P., MACAUDEERE, J., SOB A, D. 1988. Origin and evolution of the Late Precambrian High-Grade Yaounde gneisses (Cameroon). Precambrian Research, 38: 91-109.

ODONNE, F. \& VIALON, P. 1983. Analogue models of folds above a wrench fault. Tectonophysics, 99: 31-46.

PASSCHIER, C.W. 1984. The generation of ductile and brittle shear bands in a low-angle mylonite zone. J. Struc. GeoL, 6: 273-281.

PASSCHIER, C.W. \& SIMPSON C. 1986. Porphyroblast systems as kinematic indicators. J. Struc. GeoL, 8: 831-844.

PLATT, J.P. \& VISSERS, R.L.M. 1980. Extensional structures in anisotropic rocks. J. Struc. GeoL, 2: 397-410.

PEDROSA-SOARES, A.C., NOCE, C.M., GROSSI SAD, J.H., D'EL-REY SILVA, L.J.H., LEONARDOS, O.H., 1994. Evolucao da Faixa Araguaf: evidencias sedimentares, litoqufmicas e tectonicas sugestivas de um prisma acrescionario Brasiliano. In CONG. BRAS. GEOL., 38, Balneario Camboriu, Bol. Res. Expandidos... Balneario Camboriii, SBG, v.l, Simposios, p.227-228.

RAMSAY, J.G. 1967. Folding and fracturing of rocks. McGraw Hill, N.Y., $568 \mathrm{p}$.

RIDLEY, J. 1986. Parallel stretching lineations and fold axes oblique to a shear displacement direction - a model and observations. J. Struc. GeoL, 8: 647-653.
ROYDEN, L. \& BURCHFIEL, B.C. 1989. Are systematic variations in thrust belt style related to plate boundary processes? (The western Alps versus the Carpatian). Tectonics, 8: 51-61.

SAES, G.S. 1984. Estratigrafia e sedimentologia do Grupo Estdncia na regido nordeste do Estado da Bahia. Salvador, 107p. (Dissertação de Mestrado, UFBa).

SANTOS, E.J., dos \& BRITO NEVES, B.B. de 1984. Provfncia Borborema. In ALMEIDA, F.F.M. de \& HASUI, Y. coord. O pre-Cambriano do Brasil. Ed. Edgard Blucher Ltda. p.123-186.

SANTOS, R.A., MENEZES FILHO, N.R., SOUZA, J.D. de 1988. Programa Levantamentos Geologicos Basicos; carta geo!6gica, carta metalogene"tica/previsional -escala 1:100.000, Projeto Carira. DNPM/CPRM, 4 vol.

SHACKLETON, R.M. 1986. Precambrian collision tectonics in Africa. In M.P. Coward \& A.C. Ries (eds) Collision Tectonics, GeoL Soc. London Sp. Pub. 19, p.329-349.

SHIMAMOTO, T. 1989. The origin of S-C mylonites and a new fault-zone model. J. Struc. Geol, 11: 51-64.

SILVA FILHO, M.A. 1976. A suite ofiolítica da Geosinclinal de Propria. In CONG. BRAS. GEOL., 29, Ouro Preto, Anais...Olim Preto, SBG, v.l, p.51-58.

SILVA FILHO, M.A. 1982. A evolugao da porgao marginal do cinturao Sergipano e sua metalogenia. In CONG. BRAS. GEOL., 32 Salvador, Anaw...Salvador, SBG, v.1, p.316-324.

SILVA FILHO, M.A. 1995. Os marcos estratigraficos na evolucao da Provincia Borborema -Nordeste do Brasil. In CONG. LAT.-AMERICANO GEOL., Caracas, Volumen de Resumenes...Car\&cas.

SILVA FILHO, M.A., BONFIM, L.F.C., SANTOS, R.A. dos 1978a. A geossinclinal Sergipana: estrutura e evolugao. In CONG. BRAS. GEOL., 30, Recife, Anais...Recife, SBG, v. 6, p.2464-2477.

SILVA FILHO, M.A., SANTANA, A.C., BONFIM, L.F.C., 1978b, Evolugao tectono-sedimentar do Grupo Estancia: suas correlacoes. In CONG. BRAS. GEOL., 30, Recife, Anais...Recife, SBG, v. 2, p.685699.

TALBOT, C.J. 1974. Fold nappes as Asymmetric Mantled gneiss Domes and Ensialic Orogeny. Tectonophysics, 24:259-276.

TANKARD, A.J. 1986. On the depositional response to thrusting and lithospheric flexure. Intern. Assoc. Sedim., Spec. Pub. 8, p.369-394.

TEIXEIRA, W. \& FIGUEIREDO, M.C.H. 1991. An outline of Early Proterozoic crustal evolution in the Sao Fancisco craton, Brazil: a review. Precambrian Research, 53: 1-22.

TORRES, H.H.F., OLIVEIRA, R.G., FIGUEIROA, I. 1994 - Endentação tectonica da extremidade norte do Craton Sao Francisco na Faixa Riacho do Pontal. In CQNG. BRAS. GEOL., 38, Balneario Camboriu, Bol. Res. Expandidos...Balneário Camboriú, SBG, v.l, p. 222-223.

TROMPETTE, R. 1994. Geology of Western Gondwana. A.A.Balkema, Rotterdam, 350p.

VAN SCHMUS, W.R., BRITO NEVES, B.B. de, HACKSPACHER, P., BABINSKI, M. 1993. Identification of crustal blocks in Northeast Brazil using Sm-Nd and U-Pb Geochronology. SIMP. CRÁTON S. FRANCISCO, 2, Salvador, Anais...Salvador, SBG-SGM p.239-242.

VAN SCHMUS, W.R., BRITO NEVES, B.B. de, HACKSPACHER, P., BABINSKI, M. 1995. U/Pb and $\mathrm{Sm} / \mathrm{Nd}$ geochronologic studies of the eastern Borborema Province, Northeastern Brazil: initial conclusions. J. S. Am. Earth Sci., 8: 267-288.

WERNICKE, B. \& BURCHFIEL, B.C. 1982. Modes of extensional tectonics. J. Struc. GeoL, 4:105-115.

WU, S. 1993. Microstructures, deformation mechanisms and strain patterns in a vertical profile, inner Appalachian fold-thrust belt, Alabama. $J$. Struc. Geol 15(2): 129-144.

MANUSCRITO No 869

Recebido em 31 de agosto de 1996

Revisao dos autores em 30 de novembro de 1996 Revisao aceita em 15 de Janeiro de 1997 